\title{
Creating and destroying jobs across East Asia Pacific: a country-level analysis on wages, exports, finance, regulation and infrastructure
}

\author{
Alexander Krauss
}

Correspondence: a.krauss@ucl.ac.uk

\begin{abstract}
This paper is the first to analyse a much broader range of correlates of job growth simultaneously for each country individually across all 12 East Asian and Pacific countries with stratified randomised enterprise survey data between 2009 and 2012. It acknowledges the strong data limitations and deviates from the standard approach of using pooled, cross-country regressions in analysing enterprise survey data which reduces the usefulness of findings for policymakers in individual countries by neglecting variations across diverse countries with unique business, regulatory and institutional environments. Potential policy responses are derived from the multivariate econometric analyses while highlighting the importance of idiosyncratic country conditions.
\end{abstract}

JEL codes: J21, J24, J30, D22

Keywords: Employment growth; Job creation; East Asia and Pacific; Enterprise survey; Business climate

\section{Introduction}

Creating jobs is of relevance for firm owners, citizens and policymakers alike. Firm owners regularly demand information on how to influence the expansion of their firms. Citizens can be negatively affected by being unemployed in terms of their levels of subjective wellbeing, as work can help give people meaning in life, connect them to other individuals and their community, provide social recognition and identity, build up skills and capacities, and provide income (Krauss and Graham 2013). Policymakers in turn often design and implement policies and programmes aimed at promoting employment growth.

The extent to which firms create jobs can be shaped by the broader business, investment and institutional environment within which they operate, i.e. by factors that can influence firms' opportunities and risks, their decisions about investments and their incentives to expand. Within this broader environment, applied economists often analyse the relationship of policy (such as improved access to infrastructure or technology) or managerial choices (such as the decision to export) with firm expansion. An abundance of research exists on the correlates of job creation globally and in OECD countries, but such research is more scarce within individual East Asian and Pacific 
countries ${ }^{1}$. Papers using enterprise surveys that analyse job growth often focus on a specific issue such as basic firm-level traits ${ }^{2}$, labour productivity ${ }^{3}$, innovation ${ }^{4}$, business regulation $^{5}$, electricity ${ }^{6}$, or finance and corruption ${ }^{7}$. By expanding on this work and broadening its scope, the first main contribution of this paper is to explore these factors but to do so simultaneously also including other factors ranging from levels of wages to other specific infrastructure and technology traits, among others. This can allow for a broader understanding of a wider range of correlates of job growth.

Most such papers, which use enterprise survey data to analyse job growth, apply pooled, cross-country regressions. This modelling approach merges idiosyncraticies within individual countries into pooled results or into the error term, making the strong assumption that correlates of job growth would be similar across countries. By assessing instead between country variations, this paper investigates this assumption and illustrates that it is not supported by empirical evidence. It identifies thereby several limitations in applying this popular approach of pooling data in the job growth literature. First, this approach can ignore much firm heterogeneity and variations between individual countries with unique business, financial and regulatory environments $^{8}$. It can ignore the fact that processes in each individual country that can link the selected dependent and independent variables vary given different labour standards, bureaucratic structures and institutions. It can ignore levels of inflation and political stability in individual countries that can influence decisions about investment and firm hiring, both domestically and abroad. It can ignore the fact that in a country with high population growth or high economic growth it would be expected to be less difficult for firms to hire new employees. Because these factors, together with other countryspecific variables, are not all included in these surveys and cannot always be controlled for in statistical models, pooled regression analysis using enterprise surveys is faced with limitations. Second, as this approach forces variations observed across countries into a single-averaged and weighted-coefficient, a result can often be influenced by a few outlier or large economies, as later illustrated. Third, it can reduce the usefulness of findings for policy in specific countries, as this paper shows that the additional pooled regional results presented here have limited value for policymakers and firm owners in individual countries given that the pooled results are almost entirely shaped by trends in China due to its large survey sample.

By analysing job growth for East Asian and Pacific countries individually, the second main contribution of this paper is thus identifying correlates of job growth within individual countries and across sub-groups of countries including the Pacific Island economies and larger economies. The country-specific analyses conducted here help reduce the assumptions and limitations of using the common approach of pooling enterprise survey data across countries. While this is not the first paper to analyse job growth at the country level using enterprise survey data, existing papers often do not conduct comparative analyses across countries or they often apply a few variables relative to the wide range applied here?

This paper is therefore the first to examine a broader range of correlates of job growth for each country separately across all East Asian and Pacific countries with enterprise survey data, which can help produce more policy-relevant results for individual countries-this is the paper's main objective. To be clear, the results here illustrate correlations of firm characteristics with job growth, not potential causal effects. Enterprise surveys do not allow for the identification of causal relationships irrespective of the 
statistical model applied (despite most existing studies cited throughout this paper claiming they establish causation) as for example many observable and non-observable household, macro and institutional level factors can influence firms and job creation and can interact with correlates but are not captured in firm-level enterprise surveys. It is important-while not common practice in research-to outline the limitations of firm-level analyses, with the paper making explicit the strong constraints in analysing enterprise survey data that many existing studies neglect to acknowledge. Being conscious and transparent about the limitations, descriptive data analysis can still provide useful information to inform policymakers.

This paper is organised as follows. Section 2 describes the data sources used for the analysis and outlines a number of important data limitations accompanying enterprise surveys. Section 3 illustrates the descriptive results. Section 4 presents the model, outlines its limitations and provides the multivariate regression results of a wide range of firm-level correlates of employment growth in individual East Asian and Pacific countries. Section 5 discusses potential policy implications and concludes.

\section{Data sources}

This paper analyses World Bank Enterprise Survey data for all 12 East Asian and Pacific countries with available data between 2009 and 2012: China, Fiji, Indonesia, Lao PDR, Micronesia, Mongolia, the Philippines, Samoa, Timor-Leste, Tonga, Vanuatu and Vietnam. The analysis thereby includes nine lower middle income countries $(\$ 1,036$ to $\$ 4,085)$ and three upper middle income countries $(\$ 4,086$ to $\$ 12,615)$ based on World Bank (2013b) GNI per capita income group classifications. The number of observations covered in each survey varies from 2,700 firms in China to 68 firms in Micronesia (see Table 1 for information of sample size).

The enterprise surveys collect firm-level data on private sector firms, with manufacturing and service sector firms being the primary business sectors of interest ${ }^{10}$. The sampling methodology applied for these cross-sectional surveys is stratified random sampling. They are stratified using three criteria: sector of activity, size of firms, and geographic location. Survey sample weights are used for all data calculations throughout this paper. Questions in the enterprise surveys are answered by firm owners or top managers (for further information on methodology, see Enterprise Surveys 2013).

Enterprise surveys, while providing a central source of data on firms and for policy prioritisation, are accompanied with a number of important limitations. They focus on private sector firms, with $100 \%$ government-owned firms not eligible to be surveyed so that rich information on government-owned establishments is lacking. They omit various regions from the data collection within many countries (restricting geographically disaggregated analysis) and they do not survey firms in the agriculture sector (Enterprise Surveys 2013), although agriculture accounts for the majority of the labour force in many countries in the region. They are accompanied with a selection bias as former firm owners, who exited the market, are not surveyed (Fox and Oviedo 2008), implying a truncation problem ${ }^{11}$. Obstacles associated with starting a business are unknown as well because only existing firm owners (not aspiring entrepreneurs) are surveyed. Detailed background information on individual business owners is not collected which inhibits trying to identify which specific factors help influence entrepreneurship. 
Conducting analysis over time is also constrained as enterprise surveys have only recently been collected, with Laos being the only country in the region having collected two survey rounds at the time of the study. In addition, survey samples are small in some countries (especially in the Pacific) so that limited observations of firms restricts deeper analysis of underlying constraints and issues ${ }^{12}$.

The enterprise surveys are thus not a 'representative' sample of an economy's private sector firms although they claim they are (Enterprise Surveys 2013). While all data sets have a number of limitations, the econometric results here can nonetheless help provide some insights into the correlates of job creation among this large sub-sample of existing, formally-registered, private sector firms in the manufacturing and service sectors. The results are not at all to be interpreted as evidence of the precise interrelationship between job growth and its potential determinants at the aggregate level.

\section{Descriptive results}

In the enterprise surveys, firms are asked, "at the end of last fiscal year and at the end of 3 fiscal years ago, how many permanent, full-time employees did this establishment employ?", making it possible to calculate the average annual employment growth rate at the firm level over the past three years ${ }^{13}$. Table 1 illustrates that the average annual job growth rate for firms over the past 3 years was highest in Mongolia, then Indonesia, followed by Vanuatu. It is important to note that these shares are very likely biased upwards, since (as mentioned) firms that shut down are not captured in the survey. In addition, positive job growth in a firm does not imply that workers were not laid off at some point, but rather the overall number of hired workers is larger than the overall number of fired workers. Also, job loss in a firm does not capture if labour-intensive work may have been replaced with another means of higher production which could for example increase a firm's total sales. That is, this paper focuses on job growth and its correlates, not on the consequences of job growth.

In all East Asian and Pacific countries, firms created, on average, more jobs than destroyed jobs-a trend also found internationally (Aterido and Hallward-Driemeier 2008). In some countries more than half of firms surveyed were employing more employees last year compared to three years ago such as in Fiji, Mongolia, Vanuatu, Vietnam and China. The countries in which the share of firms shedding jobs was highest are Laos and Vietnam. It appears that Vietnam has therefore a very dynamic job market as it has relatively high shares of firms expanding (55.2\%) and shrinking (28.9\%) in terms of employees.

In disaggregating the data and only analysing firms that experienced employment growth across the region, Table 1 also illustrates that the majority of growth over the past three years has been driven by firms with 15 or less employees. In terms of job destruction, there is also a very strong bias towards micro and small firms as they shed the majority of jobs in all countries in the region. In analysing job growth experienced by firms across different sectors of activity, it is important to note that growth patterns can be strongly influenced by the share of firms in each respective sector. An example is that in Indonesia manufacturing firms experienced most job creation (Table 1), while most firms in the country are active in the manufacturing sector (Table 2). By crossing data on initial firm size (3 years ago) with average job growth rates (annualised over the 
Table 1 Descriptive summary statistics on job growth and job destruction across East Asia Pacific over the past 3 years

\begin{tabular}{|c|c|c|c|c|c|c|c|c|c|c|c|c|}
\hline & China & Fiji & Indonesia & Lao PDR & Micronesia & Mongolia & Philippines & Samoa & Timor-Leste & Tonga & Vanuatu & Vietnam \\
\hline Average annual job growth rate & 0.08 & 0.07 & 0.15 & 0.04 & 0.09 & 0.28 & 0.07 & 0.07 & 0.10 & 0.01 & 0.13 & 0.10 \\
\hline Std. Dev. & 0.15 & 0.18 & 0.42 & 0.27 & 0.24 & 1.03 & 0.48 & 0.16 & 0.34 & 0.08 & 0.25 & 0.34 \\
\hline \multicolumn{13}{|l|}{$\%$ of firms experiencing: } \\
\hline Job creation & 68.6 & 53.6 & 47.1 & 34.8 & 43.6 & 61.4 & 31.5 & 45.5 & 40.9 & 28.1 & 62.1 & 55.2 \\
\hline Job destruction & 8.1 & 24.4 & 16.9 & 28.2 & 25.6 & 18.4 & 18.1 & 19.7 & 13.1 & 24.7 & 14.4 & 28.9 \\
\hline No change in \# of employees & 23.3 & 22 & 36 & 37 & 30.8 & 20.2 & 50.5 & 34.8 & 46 & 47.2 & 23.5 & 15.9 \\
\hline Total & 100 & 100 & 100 & 100 & 100 & 100 & 100 & 100 & 100 & 100 & 100 & 100 \\
\hline \multicolumn{13}{|c|}{ Of firms experiencing job creation, $\%$ that have: } \\
\hline$<=5$ employees (initial size) & 8.6 & 29.4 & 70.8 & 19.8 & 24.8 & 17.1 & 13.6 & 20.4 & 49.8 & 42.1 & 13.0 & 16.5 \\
\hline 6-15 employees & 43.1 & 39.4 & 22.9 & 35.7 & 45.1 & 42.0 & 31.8 & 54.7 & 32.3 & 45.9 & 46.5 & 34.1 \\
\hline 16-30 employees & 12.8 & 11.7 & 1.7 & 10.1 & 18.8 & 19.2 & 20.7 & 13.8 & 11.8 & 11.5 & 27.1 & 16.2 \\
\hline $31+$ employees & 35.5 & 19.6 & 4.7 & 34.5 & 11.3 & 21.7 & 33.8 & 11.2 & 6.2 & 0.5 & 13.5 & 33.2 \\
\hline Total & 100 & 100 & 100 & 100 & 100 & 100 & 100 & 100 & 100 & 100 & 100 & 100 \\
\hline \multicolumn{13}{|c|}{ Of firms experiencing job creation, \% in: } \\
\hline Manufacturing sector ${ }^{a}$ & 54.2 & 16.1 & 84.1 & 45.3 & 9.8 & 24.1 & 19.5 & 18.4 & 32.2 & 21.6 & 6.6 & 43.8 \\
\hline Service sector & 43.4 & 81.3 & 14.8 & 47.3 & 86.5 & 43.5 & 76.8 & 71.2 & 41.0 & 78.4 & 82.5 & 44.9 \\
\hline Other sectors & 2.4 & 2.6 & 1.1 & 7.4 & 3.8 & 32.4 & 3.7 & 10.4 & 26.8 & 0.0 & 10.9 & 11.3 \\
\hline Total & 100 & 100 & 100 & 100 & 100 & 100 & 100 & 100 & 100 & 100 & 100 & 100 \\
\hline Sample size & 2,700 & 164 & 1,444 & 233 & 68 & 362 & 1,326 & 109 & 150 & 150 & 128 & 1,053 \\
\hline Survey year & 2012 & 2009 & 2009 & 2012 & 2009 & 2009 & 2009 & 2009 & 2009 & 2009 & 2009 & 2009 \\
\hline
\end{tabular}

Source: Author's calculations based on enterprise survey data. Note: The average annual job growth rate at the firm level ranges from $<0$ for job destruction to $>0$ for job creation, and $=0$ for no change in the number of employees. ${ }^{a}$ Manufacturing includes textiles, leather, garments, food, metals and machinery, electronics, chemicals and pharmaceuticals, wood and furniture, non-metallic and plastic materials, auto and auto components, and other manufacturing sectors; services include retail and wholesale trade, hotels and restaurants, and other services; other sectors include sectors such as construction and transportation. 
Table 2 Summary statistics of overall business environment traits in East Asia Pacific

\begin{tabular}{|c|c|c|c|c|c|c|c|c|c|c|c|c|}
\hline All shares are out of $100 \%$ unless otherwise indicated & China & Fiji & Indonesia & Lao PDR & Micronesia & Mongolia & Philippines & Samoa & Timor-Leste & Tonga & Vanuatu & Vietnam \\
\hline \multicolumn{13}{|l|}{ Basic firm-level traits } \\
\hline Initial firm size, $<=5$ employees & 9.2 & 23.0 & 44.2 & 21.2 & 15.7 & 16.2 & 11.0 & 13.3 & 28.2 & 41.8 & 14.3 & 12.8 \\
\hline Initial firm size, 6-15 employees & 44.1 & 40.5 & 42.4 & 40.6 & 51.8 & 37.0 & 38.8 & 49.6 & 38.8 & 46.0 & 49.4 & 27.2 \\
\hline Initial firm size, $16-30$ employees & 14.9 & 17.4 & 6.1 & 9.7 & 19.3 & 24.6 & 21.2 & 17.5 & 17.1 & 11.7 & 24.0 & 24.2 \\
\hline \multirow[t]{2}{*}{ Initial firm size, 31+ employees } & 31.9 & 19.1 & 7.3 & 28.4 & 13.1 & 22.2 & 29.0 & 19.7 & 15.9 & 0.6 & 12.4 & 35.7 \\
\hline & 100 & 100 & 100 & 100 & 100 & 100 & 100 & 100 & 100 & 100 & 100 & 100 \\
\hline Firms $<10$ years old & 41.2 & 24.5 & 36.7 & 40.2 & 31.4 & 49.3 & 36.4 & 27.4 & 89.8 & 54.7 & 44.2 & 65.1 \\
\hline Firms $10-19$ years old & 51.0 & 27.2 & 39.4 & 41.6 & 37.9 & 44.7 & 32.9 & 37.0 & 8.5 & 29.7 & 24.2 & 23.5 \\
\hline \multirow[t]{2}{*}{ Firms $>=20$ years old } & 7.8 & 48.4 & 23.9 & 18.3 & 30.8 & 6.1 & 30.8 & 35.7 & 1.7 & 15.7 & 31.6 & 11.4 \\
\hline & 100 & 100 & 100 & 100 & 100 & 100 & 100 & 100 & 100 & 100 & 100 & 100 \\
\hline Manufacturing sector & 50.6 & 16.0 & 82.0 & 30.7 & 12.4 & 26.6 & 22.7 & 19.7 & 38.0 & 15.0 & 7.9 & 38.8 \\
\hline Service sector & 47.2 & 80.5 & 15.5 & 62.7 & 80.3 & 47.8 & 72.4 & 70.2 & 39.9 & 83.8 & 73.0 & 48.8 \\
\hline \multirow[t]{2}{*}{ Other sectors } & 2.2 & 3.5 & 2.5 & 6.6 & 7.3 & 25.6 & 5.0 & 10.2 & 22.1 & 1.2 & 19.2 & 12.4 \\
\hline & $\begin{array}{l}100 \\
95.8\end{array}$ & $\begin{array}{l}100 \\
93.5\end{array}$ & $\begin{array}{l}100 \\
29.1\end{array}$ & $\begin{array}{l}100 \\
83.7\end{array}$ & $\begin{array}{l}100 \\
96.9\end{array}$ & $\begin{array}{l}100 \\
90.1\end{array}$ & $\begin{array}{l}100 \\
97.5\end{array}$ & $\begin{array}{l}100 \\
88.4\end{array}$ & $\begin{array}{l}100 \\
91.7\end{array}$ & $\begin{array}{l}100 \\
93.5\end{array}$ & $\begin{array}{l}100 \\
88.1\end{array}$ & $\begin{array}{l}100 \\
875\end{array}$ \\
\hline Firm is incorporated & 35.6 & 53.0 & 14.8 & 3.9 & 6.0 & 96.0 & 59.9 & 49.4 & 6.9 & 19.9 & 21.9 & 64.0 \\
\hline Sole proprietorship (firm owned and managed by one person) & 50.8 & 39.8 & 84.3 & 91.9 & 60.6 & 1.8 & 24.3 & 46.3 & 83.7 & 65.5 & 67.2 & 25.9 \\
\hline Firm is foreign owned, partly or fully & 5.0 & 11.9 & 1.8 & 10.0 & 26.6 & 8.7 & 13.6 & 21.3 & 17.5 & 13.5 & 36.0 & 9.5 \\
\hline Firm is partly government owned & 3.1 & 0.6 & 0.3 & 0.8 & 0.0 & 0.1 & 0.4 & 1.8 & 0.5 & 1.4 & 0.0 & 7.4 \\
\hline Share of unskilled employees & 49.6 & - & 20.3 & 30.9 &.- & 29.5 & 10.8 & - & - & -.4 & - & 20.8 \\
\hline Share of female employees & 37.8 & 37.3 & 36.8 & 46.4 & 37.3 & 48.5 & 39.2 & 34.4 & 22.8 & 56.3 & 37.7 & 36.1 \\
\hline \multicolumn{13}{|l|}{ Firm-level business climate, technology and infrastructure traits } \\
\hline Share of firms that export & 10.9 & 15.6 & 2.7 & 21.3 & 35.4 & 5.0 & 7.8 & 14.8 & 1.0 & 3.3 & 27.4 & 14.9 \\
\hline Email use for doing business & 85.0 & 86.0 & 13.2 & 42.4 & 85.1 & 62.0 & 67.8 & 86.5 & 47.2 & 56.5 & 83.5 & 83.2 \\
\hline Provides formal training to workers & 79.2 & 61.0 & 4.7 & 26.9 & 58.3 & 61.2 & 31.1 & 79.1 & 49.7 & 11.1 & 47.5 & 43.6 \\
\hline Has a generator & 8.0 & 27.8 & 6.4 & 12.2 & 43.9 & 24.2 & 40.8 & 18.6 & 41.9 & 75.5 & 33.4 & 34.8 \\
\hline$\#$ of power outages in a typical month last fiscal year & 0.3 & 1.7 & 2.8 & 2.7 & 5.8 & 3.0 & 1.0 & 5.4 & 14.1 & 2.1 & 2.8 & 2.0 \\
\hline Had 3 or more power outages in a typical month last year, $\%$ & 1.2 & 20.0 & 26.3 & 41.2 & 68.9 & 33.1 & 13.8 & 70.9 & 91.5 & 27.7 & 28.3 & 27.3 \\
\hline \multicolumn{13}{|l|}{ Firm-level business regulation traits } \\
\hline \# of days needed to obtain operating license & 27.5 & 6.5 & 21.1 & 13.1 & 7.3 & 43.5 & 10.6 & 6.1 & 16.6 & 3.3 & 21.6 & 17.8 \\
\hline Firm has ISO certification & 53.4 & 22.9 & 2.9 & 11.9 & 6.0 & 16.7 & 15.7 & 31.4 & 2.2 & 7.8 & 27.0 & 16.7 \\
\hline Firm has external auditor & 63.3 & 90.1 & 4.0 & 31.7 & 25.2 & 79.0 & 91.1 & 71.7 & 20.8 & 45.2 & 43.6 & 30.1 \\
\hline Management's time dealing w/government regulations, \% & 1.5 & 6.4 & 2.4 & 7.7 & 15.4 & 13.0 & 11.1 & 17.5 & 5.8 & 6.6 & 9.2 & 5.3 \\
\hline Spends $5 \%$ or more of time w/government regulations, $\%$ & 7.4 & 29.9 & 15.0 & 42.7 & 50.5 & 65.2 & 53.3 & 60.2 & 44.4 & 75.5 & 54.8 & 28.9 \\
\hline$\#$ of hours per week firm operated last year & 51.8 & - & 52.3 & - & - & 52.6 & 66.5 & - & - & - & - & 61.7 \\
\hline \multicolumn{13}{|l|}{ Firm-level financial climate traits } \\
\hline Has checking and/or savings account & 96.0 & 96.1 & 51.5 & 78.2 & 98.5 & 61.4 & 97.8 & 97.0 & 87.7 & 100 & 96.0 & 89.4 \\
\hline Has credit line or loan from a bank & 25.3 & 37.8 & 18.2 & 29.3 & 43.0 & 52.9 & 33.2 & 51.3 & 6.9 & 54.3 & 45.8 & 49.9 \\
\hline & 24.1 & 55.6 & 5.8 & - & 12.5 & 35.7 & 28.7 & 63.2 & 15.8 & 40.2 & 53.2 & 12.3 \\
\hline \multicolumn{13}{|l|}{ Firm-level tax and corruption traits } \\
\hline Firm visited/inspected by tax officials last year & 59.4 & 61.3 & 11.7 & 93.8 & 56.1 & 68.0 & 87.2 & 52.1 & 44.3 & 21.9 & 75.2 & 61.1 \\
\hline Firm gives informal payments to public officials (for license, tax etc.) & 3.4 & 8.9 & 9.3 & 17.6 & 0.0 & - & 16.1 & 13.5 & 13.1 & 0.2 & 3.4 & 19.4 \\
\hline Sample size & 2700 & 164 & 1444 & 233 & 68 & 362 & 1326 & 109 & 150 & 150 & 128 & 1053 \\
\hline
\end{tabular}

Source: Author's calculations based on enterprise survey data. ${ }^{a}$ Mongolia has been omitted from the survey sample of firms paying informal payments/gifts to public officials given limited observations. Additional tables of summary statistics including values on minimum, maximum, and standard deviation are not included due to space limitations. 
last 3 years), the data illustrate that firms with five or less employees experienced overall the highest job growth rates across East Asia Pacific countries (see Figure 1 in the Appendix).

Table 2 provides summary statistics for the variables applied in the regression analyses. Micro and small firms with less than 15 employees and firms less than 20 years old account for the majority of employers in most countries in the region. In the Pacific Island countries, the vast majority of employers are concentrated in the service sector, while in Indonesia and China, the manufacturing sector has the highest firm density. In terms of levels of incorporation, less than $15 \%$ of firms had such legal status in Indonesia, Laos, Micronesia and Timor-Leste. Indonesia has the lowest share of firms that are formally registered when they start their business and high shares of firms that are a sole proprietorship.

In terms of electricity, it appears that some governments are constrained in providing equitable access to reliable electricity infrastructure, as the average firm in Micronesia, Samoa and particularly Timor-Leste reports at least five power outages per month. Ensuring a reliable and affordable flow of electricity can help enable businesses to produce more value-added products, helps to free up time from household tasks and can thus increase levels of female employment (Dinkelman 2011) ${ }^{14}$. In terms of obtaining an operating license, firms had to wait on average longest in Mongolia, a total of 43.5 days, calculated from the day the firm applied to the day it was granted. It is worth noting that within the Philippines there is very large variation between firms in the number of days needed to receive their license, suggesting that corruption may play a role here (see also Hallward-Driemeier et al. 2010). As to the number of hours per week operated by firms, Filipino firms have the longest operating weeks at 66.5 hours.

Turning to financial infrastructure, over $90 \%$ of firms have a checking and/or savings account in China, the Philippines and the Pacific Islands, while this share reduces to about half of firms in Indonesia. Countries in which about $50 \%$ or more of firms have a credit line or loan from a financial institution include Mongolia, Samoa, Tonga and Vietnam. This can facilitate investment and longer-term planning and helps mitigate potential shocks in capital shortages and smooth business cycle fluctuations. Wellfunctioning financial markets can also connect firms to lenders and investors able to finance business ventures and share risks (World Bank 2004; IFC 2012).

In contrast to other countries, nearly all firms in Laos and the Philippines were inspected by tax officials last year. In terms of bribes, two-digit shares of firms made gifts or informal payments to public officials to 'get things done' (for licenses, customs, taxes, regulations etc.) in several countries such as Laos and the Philippines. In sum, Table 2 illustrates that significant differences exist between countries in the quality of the business and institutional climate within which firms operate.

\section{Regression results}

\subsection{Regression model 1 and results}

Multivariate analysis is applied to explore the correlates of a wide range of factorswithin the overall business, investment and institutional environment-of job creation. The analysis is conducted using ordinary least squares (OLS) regressions, which is the standard approach in the literature analysing job growth using enterprise surveys (see 
for example: Rutkowski 2003; Ayyagari et al. 2011; Dutz et al. 2011). The dependent variable is the average annualised job growth rate of firms over the past three fiscal years (as defined earlier). With job growth expressed here in annual percentage terms (not in $\log$ ), it is possible to interpret estimated coefficients as the change in the percentage job growth rate relative to a unit increase in the regressor. The selection of independent variables for the models has been in part influenced by previous papers that identify relevant correlates of employment growth in other regions and globally-in particular, Fox and Oviedo (2008), Pagés et al. (2007), Dutz et al. (2011), and Shi and Michelitsch (2012). Incorporating various variables identified as important in these papers simultaneously and also including a number of additional variables identified as relevant in the descriptive results earlier, the paper here attempts to reduce levels of omitted variable bias ${ }^{15}$. The independent variables analysed here range from initial level of employment in the base year and other basic firm-level traits (such as age and location) to sector of activity (manufacturing, services and other sectors), wage and productivity levels, technology and infrastructure (email use, exports and electricity), business regulation and finance, as well as corruption, among other factors.

Yet in contrast to the papers listed above that run cross-country pooled regressions, this paper explores the correlates of job growth in each country individually-with the advantages of this approach outlined in the introduction. Interpreting econometric results is also generally easier in single country regressions as outcomes are linked to country specific circumstances. Because the regressions are conducted for each country, the main value is in comparing the correlates of specific firm traits and endowments within a country, not between countries-while across countries it can be useful to identify trends and assess whether a variable's correlate is consistently negative or positive and consistently significant.

Before presenting the results it is important-while not common practice in research-to outline the limitations of firm-level analyses, with the strong constraints of enterprise survey data already outlined in Section 2. In terms of unobserved factors in such analyses, a number of (especially non-firm level) variables can influence job creation that are not included in the firm-level enterprise survey data and thus in the regression models. The explanatory power of the model specification is thus not particularly high for a few countries such as the Philippines, for example, at 0.10. These unobserved factors can include the rule of law, governance, labour regulations, firms' specific hiring and firing costs, and macroeconomic variables such as inflation, per capita income and economic output. They can also include occupational decisions made in households and social norms about employment. In particular, fertility rates and dependency ratios can largely drive employment growth in the longer-term (see e.g. World Bank 2012), which cannot be controlled for using firm-level survey data. Such factors can be important as they can potentially influence firms differently across different regions within a country. Yet data at the sub-national level for many such factors are often difficult to obtain and data are not merged from other sources (for those variables where data exist) into the enterprise-level dataset used here. This would require a number of important assumptions given different data collection methodologies, data collected at different times of the year from different sources with different time-lags etc. Such omitted variables can be a limitation as they (such as fertility rates, for example) can be correlated at times with independent variables (such as firm size or city size, for example) so that there may likely be a correlation between the error term and independent variables. 
This paper instead takes a particular focus on exploring specific enterprise-level factors that can possibly influence job creation in the shorter-term, i.e. over a three year period.

It is important to also note that endogeneity affects all analyses using enterprise survey data ${ }^{16}$. To try and reduce further levels of measurement error and endogeneity, the models applied here do not include subjective measures as variables (such as firm perceptions of whether access to finance is a major constraint) but rather only objective measures are used (such as actual information on whether a firm has a credit line or loan). An example is that it is more likely for successful entrepreneurs (whose firms grew) to view the business climate as having fewer constraints compared to those with less success (i.e. a potential frame-of-reference bias). Another example is that it is conceivable that many firms will complain about levels of taxation as a constraint, while they may not weigh the social benefits (e.g. skill levels of their employees) and economic benefits (e.g. road and port infrastructure to move their products) associated with taxation that they and society receive. There is also the issue of latent heterogeneity in personality traits of firm owners. Many firm-level econometric analyses nonetheless include subjective indicators in their models (see e.g. Beck et al. 2005; Ayyagari et al. 2008; Carlin and Schaffer 2012).

Results for model 1 are presented in the following. Table 3 illustrates that micro and small firms can be a strong and consistent correlate of employment growth across individual East Asian and Pacific countries. Initial firm size at the baseline year (three fiscal years ago) is used here instead of current firm size to reduce levels of endogeneity related to firm growth over this period. In an incremental fashion, the smaller the firm the more number of employees were likely to be hired over the past three years. These results reflect the likelihood for a simulated firm that would have the same age, sector of activity, wage levels and, among others, infrastructure traits as an average firm but would have either a smaller or larger number of employees in the base year. These results here are consistent with international findings ${ }^{17}$ and can likely be partly explained by greater levels of substitution of labour for capital and technology among larger firms. Another possible explanation is that smaller firms are more likely to benefit from lax enforcement of regulations including labour and tax regulations, while larger firms generally spend more time dealing with public officials and red tape (Pagés et al. 2007).

Younger firms, particularly in China, Indonesia, Laos, Mongolia, Tonga and Vanuatu, appear to grow overall faster-a trend found globally (Evans 1987; Dutz et al. 2011; Ayyagari et al. 2011; Fox and Oviedo 2008; Shi and Michelitsch 2012). A possible explanation is that younger firms engage more frequently in introducing new technology or a new product (World Bank 2012). Large cities, while on one hand providing potential agglomeration effects, generally have higher levels of competition, on the other. Being located in the capital or in a city with over one million people is positively and significantly correlated with firm expansion in China, Fiji and Vietnam, i.e. larger cities were more likely to be growth poles. Yet in Indonesia and the Philippines, smaller cities were more likely to experience job growth.

In terms of sector of activity, there appears to be a bias in job growth towards service sector firms in the Pacific Island countries (except for Tonga). In China and Indonesia, it was manufacturing firms that were most likely to employ more workers. Other sectors such as construction and transportation were correlated with the strongest 
Table 3 Correlates of job growth among basic firm-level features and overall business climate traits including wages, infrastructure, regulation and finance, in East Asia Pacific over the last 3 years (model 1)

\begin{tabular}{|c|c|c|c|c|c|c|c|c|c|c|c|c|}
\hline \multirow{2}{*}{$\begin{array}{l}\text { Dependent variable: Job growth rate, } \\
\text { annual }\end{array}$} & \multicolumn{2}{|l|}{ China } & \multicolumn{2}{|l|}{ Fiji } & \multicolumn{2}{|l|}{ Indonesia } & \multicolumn{2}{|l|}{ Laos } & \multicolumn{2}{|c|}{ Micronesia } & \multicolumn{2}{|l|}{ Mongolia } \\
\hline & Coef. & tstat & Coef. & tstat & Coef. & tstat & Coef. & tstat & Coef. & tstat & Coef. & tstat \\
\hline \multicolumn{13}{|l|}{ Basic firm-level traits } \\
\hline Initial firm size, $<=5$ emp. (ref. 31+) & $0.130^{* * *}$ & 188.5 & $0.160^{* * *}$ & 4.3 & $0.359^{* * *}$ & 85.7 & $0.091^{* * *}$ & 3.3 & $0.970^{* * *}$ & 8.4 & $2.600^{* * *}$ & 22.1 \\
\hline Initial firm size, 6-15 emp. & $0.043^{* * *}$ & 97.6 & $0.139^{* * *}$ & 4.8 & $0.067^{* * *}$ & 16.6 & 0.038 & 1.6 & 0.100 & 1.4 & $0.597^{* * *}$ & 6.4 \\
\hline Initial firm size, 16-30 emp. & $0.007^{* * *}$ & 14.1 & 0.040 & 1.4 & $-0.012^{* *}$ & -2.3 & -0.038 & -1.2 & $0.174^{* *}$ & 2.1 & $0.325^{* * *}$ & 3.5 \\
\hline Firms $<10$ years old (ref. $>=20$ ) & $0.035^{* * *}$ & 53.3 & 0.023 & 0.7 & $0.016^{* * *}$ & 6.4 & $0.051^{* *}$ & 2.1 & -0.031 & -0.5 & 0.019 & 0.1 \\
\hline Firms $10-19$ years old & $0.010^{* * *}$ & 16.4 & -0.018 & -0.9 & $0.069^{* * *}$ & 28.7 & 0.021 & 1.0 & 0.087 & 1.5 & $0.416^{* * *}$ & 3.2 \\
\hline City w/1 mil. or capital (ref. small city) & $0.015^{* * *}$ & 8.4 & $0.070^{* * *}$ & 3.2 & $-0.046^{* * *}$ & -24.0 & - & _- & - & _- & 0.090 & 1.2 \\
\hline Manufacturing (ref. other sectors) & $0.042^{* * *}$ & 40.5 & $0.098^{* *}$ & 2.2 & $0.030^{* * *}$ & 4.0 & $-0.141^{* * *}$ & -3.7 & -0.038 & -0.3 & $-1.078^{* * *}$ & -11.0 \\
\hline Services & $-0.002^{* *}$ & -2.4 & $0.188^{* * *}$ & 5.5 & 0.005 & 0.6 & $-0.135^{* * *}$ & -3.7 & $0.239^{* *}$ & 2.2 & $-1.234^{* * *}$ & -12.0 \\
\hline Formally registered when opened & $0.005^{* * *}$ & 6.8 & 0.020 & 0.5 & $-0.024^{* * *}$ & -9.9 & -0.016 & -0.8 & $0.366^{* *}$ & 2.4 & $0.250^{* *}$ & 2.3 \\
\hline Sole proprietorship & $-0.013^{* * *}$ & -38.1 & -0.018 & -1.0 & $-0.153^{* * *}$ & -50.7 & -0.016 & -0.4 & $-0.189^{* * *}$ & -3.1 & -0.217 & -0.9 \\
\hline Firm is foreign owned, partly or fully & $0.010^{* * *}$ & 12.3 & $0.065^{* * *}$ & 2.6 & $0.095^{* * *}$ & 12.2 & $0.088^{* *}$ & 2.5 & 0.008 & 0.1 & -0.082 & -0.8 \\
\hline Share of female employees & $-0.052^{* * *}$ & -63.3 & $-0.139 * * *$ & -5.3 & $-0.066^{* * *}$ & -24.9 & $-0.067^{* *}$ & -2.4 & $-0.245^{*}$ & -2.0 & $-0.484^{* * *}$ & -3.7 \\
\hline \multicolumn{13}{|l|}{ Wage and productivity traits } \\
\hline Wage per worker, tercile 2 (ref. ter. 1) & $0.021^{* * *}$ & 48.4 & $-0.144^{* * *}$ & -5.8 & $-0.108^{* * *}$ & -48.2 & $-0.036^{*}$ & -1.8 & $-0.242^{* * *}$ & -3.2 & $-0.216^{* * *}$ & -2.8 \\
\hline Wage per worker, tercile 3 & $0.016^{* * *}$ & 35.6 & 0.022 & 0.9 & $-0.112^{* * *}$ & -34.0 & $-0.039^{*}$ & -1.9 & $-0.254^{* * *}$ & -2.8 & $-0.438^{* * *}$ & -5.1 \\
\hline Labour productivity (sales/employ.), In & $-0.008^{* * *}$ & -48.4 & $-0.066^{* * *}$ & -9.8 & $-0.007^{* * *}$ & -7.4 & -0.002 & -0.4 & $0.050^{*}$ & 1.9 & -0.005 & -0.2 \\
\hline Firm exports & $0.025 * *$ & 43.9 & 0.030 & 0.8 & $0.169^{* * *}$ & 27.4 & 0.036 & 1.5 & _ & _- & $0.347^{* * *}$ & 28 \\
\hline Has 3 or + power outages a month & _- & - & $0.183^{* * *}$ & 8.2 & _- & - & $-0.028^{*}$ & -1.7 & 0.082 & 1.3 & $0.773 * *$ & 11.5 \\
\hline \multicolumn{13}{|l|}{ Business requlation traits } \\
\hline Firm has ISO certification & $-0.022^{* * *}$ & -62.4 & $-0.103^{* * *}$ & -4.1 & $-0.028^{* * *}$ & -4.5 & $-0.078^{* * *}$ & -3.0 & -0.000 & -0.0 & $-0.394^{* * *}$ & -4.6 \\
\hline Spends $5+\%$ of time w/regulations & $0.044^{* * *}$ & 66.2 & $-0.053^{* * *}$ & -2.8 & $-0.014^{* * *}$ & -5.0 & $0.055^{* * *}$ & 3.1 & -0.056 & -0.9 & $-0.275^{* * *}$ & -4.0 \\
\hline \multicolumn{13}{|l|}{ Financial climate and corruption traits } \\
\hline Has credit line or loan from a bank & $0.028 * * *$ & 66.6 & -0.036 & -1.6 & $-0.015^{* * *}$ & -6.2 & $0.065^{* * *}$ & 3.6 & 0.042 & 0.7 & -0.068 & -1.0 \\
\hline Gives informal payments to officials & $-0.064^{* * *}$ & -66.3 & $-0.105^{* *}$ & -2.3 & $0.087^{* * *}$ & 25.7 & - & - & - & - & & - \\
\hline Constant & $0.102^{* * *}$ & 35.2 & $0.606^{* * *}$ & 7.4 & $0.250^{* * *}$ & 14.2 & 0.187 & 1.6 & $-0.794^{* *}$ & -2.2 & $0.729^{*}$ & 1.7 \\
\hline Observations & 1727 & & 45 & & 857 & & 160 & & & & 177 & \\
\hline Adjusted R-squared & 0.134 & & 0.526 & & 0.182 & & 0.174 & & 0.828 & & 0.466 & \\
\hline
\end{tabular}


Table 3 Correlates of job growth among basic firm-level features and overall business climate traits including wages, infrastructure, regulation and finance, in East Asia Pacific over the last 3 years (model 1) (Continued)

\begin{tabular}{|c|c|c|c|c|c|c|c|c|c|c|c|c|}
\hline \multirow{2}{*}{$\begin{array}{l}\text { Dependent variable: Job growth rate, } \\
\text { annual }\end{array}$} & \multicolumn{2}{|c|}{ Philippines } & \multicolumn{2}{|l|}{ Samoa } & \multicolumn{2}{|c|}{ Timor-Leste } & \multicolumn{2}{|l|}{ Tonga } & \multicolumn{2}{|l|}{ Vanuatu } & \multicolumn{2}{|l|}{ Vietnam } \\
\hline & Coef. & tstat & Coef. & tstat & Coef. & tstat & Coef. & tstat & Coef. & tstat & Coef. & tstat \\
\hline \multicolumn{13}{|l|}{ Basic firm-level traits } \\
\hline Initial firm size, $<=5$ emp. (ref. $31+$ ) & $0.327^{* * *}$ & 26.3 & $0.287^{* * *}$ & 4.8 & 0.104 & 1.0 & $0.120^{* * *}$ & 3.1 & -0.142 & -1.1 & $0.508^{* * *}$ & 23.7 \\
\hline Initial firm size, 6-15 emp. & $0.084^{* * *}$ & 9.1 & 0.022 & 0.4 & 0.154 & 1.7 & $0.076^{*}$ & 2.0 & 0.029 & 0.3 & $0.523^{* * *}$ & 31.7 \\
\hline Initial firm size, 16-30 emp. & $0.061^{* * *}$ & 6.4 & $-0.176^{* *}$ & -2.1 & -0.023 & -0.2 & 0.009 & 0.2 & 0.129 & 1.2 & $0.180^{* * *}$ & 10.9 \\
\hline Firms $<10$ years old (ref. $>=20$ ) & $-0.067^{* * *}$ & -7.4 & -0.001 & -0.0 & -0.104 & -0.4 & $0.026^{* *}$ & 2.1 & $0.227^{* * *}$ & 2.9 & $-0.049^{* *}$ & -2.5 \\
\hline Firms $10-19$ years old & $-0.078^{* * *}$ & -9.8 & $-0.141^{* * *}$ & -3.3 & 0.060 & 0.2 & $0.029^{* *}$ & 2.1 & $0.196^{* *}$ & 2.6 & 0.025 & 1.3 \\
\hline City w/1 mil. or capital (ref. small city) & $-0.016^{* *}$ & -2.1 & -0.094 & -0.9 & - & - & - & - & - & - & $0.108^{* * *}$ & 7.3 \\
\hline Manufacturing (ref. other sectors) & 0.035 & 0.9 & $-0.104^{*}$ & -1.8 & $-0.200^{* *}$ & -2.4 & $0.113^{* * *}$ & 9.5 & 0.041 & 0.3 & $-0.154^{* * *}$ & -7.7 \\
\hline Services & $0.073^{*}$ & 1.9 & 0.031 & 0.5 & $-0.147^{*}$ & -1.8 & - & - & $0.184^{* *}$ & 2.1 & $-0.259^{* * *}$ & -12.1 \\
\hline Formally registered when opened & $0.074^{* * *}$ & 4.1 & -0.071 & -1.2 & -0.115 & -1.1 & $0.066^{* * *}$ & 3.0 & 0.003 & 0.0 & $0.185^{* * *}$ & 12.3 \\
\hline Sole proprietorship & $-0.046^{* * *}$ & -5.6 & -0.052 & -1.5 & $-0.209^{* *}$ & -2.5 & -0.006 & -0.5 & $0.110^{*}$ & 1.7 & $-0.133^{* * *}$ & -11.3 \\
\hline Firm is foreign owned, partly or fully & $0.042^{* * *}$ & 4.1 & 0.010 & 0.2 & -0.006 & -0.1 & $-0.038^{* * *}$ & -2.9 & -0.019 & -0.3 & $0.106^{* * *}$ & 5.0 \\
\hline $\begin{array}{l}\text { Share of female employees } \\
\text { Wage and productivity traits }\end{array}$ & $-0.077^{* * *}$ & -5.9 & $0.200^{* * *}$ & 3.0 & $-0.262^{*}$ & -1.8 & $-0.090^{* * *}$ & -4.0 & -0.150 & -1.3 & $0.064^{* * *}$ & 2.9 \\
\hline \multicolumn{13}{|l|}{ Wage and productivity traits } \\
\hline $\begin{array}{l}\text { Wage per worker, tercile } 2 \text { (ref. ter. 1) } \\
\text { Wage per worker tercile } 3\end{array}$ & $\begin{array}{l}-0.056^{* * \pi} \\
-0.051^{* * *}\end{array}$ & $\begin{array}{l}-6.0 \\
-4.9\end{array}$ & $\begin{array}{l}-0.083^{* *} \\
-0198^{* * *}\end{array}$ & $\begin{array}{l}-2.3 \\
-47\end{array}$ & $\begin{array}{l}-0.125^{*} \\
-0127^{*}\end{array}$ & $\begin{array}{r}-1.8 \\
-17\end{array}$ & -0.008 & -0.7 & 0.046 & 0.7 & $-0.151^{* * *}$ & -10.4 \\
\hline & -0.051 1 & & -0.198 & & $-0.12 /^{*}$ & -1.7 & -0.019 & -1.6 & -0.067 & -0.9 & $-0.265^{* * *}$ & -17.8 \\
\hline \multicolumn{13}{|l|}{ Infrastructure traits } \\
\hline Firm exports & $0.024^{* *}$ & 2.1 & -0.052 & -1.0 & -0.210 & -1.1 & 0.024 & 1.0 & - & - & $0.042^{* * *}$ & 2.7 \\
\hline Has 3 or + power outages a month & $0.076^{* * *}$ & 7.7 & $-0.131^{* * *}$ & -3.2 & - & - & 0.016 & 1.5 & $0.167^{* *}$ & 2.4 & $-0.077^{* * *}$ & -6.9 \\
\hline \multicolumn{13}{|l|}{ Business regulation traits } \\
\hline Firm has ISO certification & $0.030^{* * *}$ & 3.0 & 0.001 & 0.0 & -0.310 & -1.3 & 0.007 & 0.4 & 0.044 & 0.6 & $0.097^{* * *}$ & 5.7 \\
\hline Spends $5+\%$ of time w/regulations & 0.009 & 1.3 & $0.101^{* * *}$ & 2.7 & 0.076 & 1.1 & 0.003 & 0.3 & $0.130^{* *}$ & 2.2 & $-0.074^{* * *}$ & -6.0 \\
\hline \multicolumn{13}{|l|}{ Financial climate and corruption traits } \\
\hline Has credit line or loan from a bank & $0.085^{* * *}$ & 11.2 & -0.042 & -1.4 & -0.007 & -0.1 & $0.030^{* * *}$ & 3.6 & 0.030 & 0.5 & $0.115^{* * *}$ & 10.5 \\
\hline Gives informal payments to officials & -0.006 & -0.7 & 0.059 & 1.3 & 0.052 & 0.5 & $0.227^{* * *}$ & 3.3 & $-0.485^{* *}$ & -2.2 & $0.035^{* *}$ & 2.5 \\
\hline Constant & 0.009 & 0.2 & $0.845^{* * *}$ & 4.5 & 0.515 & 1.5 & $0.284^{* * *}$ & 4.3 & 0.354 & 0.8 & $0.658^{* * *}$ & 6.9 \\
\hline Observations & 494 & & 41 & & 60 & & 73 & & 58 & & 350 & \\
\hline Adjusted R-squared & 0.103 & & 0.615 & & 0.197 & & 0.416 & & 0.257 & & 0.194 & \\
\hline
\end{tabular}

Source: Author's regression results based on calculations of enterprise survey data. Note: ***p<0.01, ${ }^{* *} \mathrm{p}<0.05,{ }^{*} \mathrm{p}<0.1$. The high $\mathrm{r}$-squared for Micronesia and Samoa should be read with caution given the small sample size in these countries. It is important to note that $5.9 \%$ of respondents for the analysis (i.e. the average for all East Asia Pacific countries analysed here) refused to respond when asked about the total annual cost of labour while $6 \%$ reported they did not know, so that a total of $11.9 \%$ of observations had to be omitted from the analysis. 
employment growth in several of the lower-middle income countries such as Lao, Mongolia, Timor-Leste and Vietnam.

Table 3 illustrates that being formally registered when firms' began operations is positively and significantly correlated with employing more workers in China, Micronesia, Mongolia, the Philippines, Tonga and Vietnam. Only in Indonesia was this relationship significantly negative, where informality is the norm and less than one third of firms are formally registered when they start their business. At the same time, as firms increase in size so does the likelihood of formalising. Sole proprietorships (unincorporated businesses with one owner) appear less likely to hire more people.

Firms that are partially or fully owned by foreign individuals, companies or organisations are overall more likely to expand their firm size, particularly in several of the larger economies in the region-(see Pagés et al. (2007)) for similar results globally. A potential channel through which foreign owned firms can contribute to higher job growth is through greater acquisition of new technical and managerial skills as well as other benefits as a result of their greater integration in international value chains (World Bank 2012).

In terms of gender, there seems to be a consistent relationship across the region between a higher share of women within a firm and lower job growth, with Samoa as an exception. This can possibly be explained in part by females not being randomly distributed across sectors, but firms with $50 \%$ or more females are disproportionately concentrated in the sectors of retail and wholesale, garments, and hotels and restaurants. These are among the highest productivity sectors (requiring thus fewer workers) as descriptive data calculations indicate. Other factors may also play a role such as maternity leave and women being more likely to balance work with household tasks and caretaking of other household members (World Bank 2004; 2012).

Worker wages, which are calculated by dividing a firm's total annual cost of labour by its total number of permanent full-time employees, are split here into terciles for each country. There is a significant relationship across all countries in the region, except China, between higher wage premiums and lower job growth. This can be often largely due to the fact that a firm that falls into the second or third tercile pays their workers on average about twice or triple as much as firms in the bottom tercile (the reference group). That is, firms in the bottom tercile account for the $33.3 \%$ of the lowest wage firms that, in principle, can hire twice or triple as many workers given their lower wages-while the model controls for different levels of earnings associated with firms being active in manufacturing, services, or other sectors. This can also be related to the nature of production, as lower wage firms (which are often lower-skilled and more labour-intensive) are more likely to hire in pace with firm expansion than higher wage firms (which are often higher-skilled and more capital-intensive).

Higher labour productivity (while often improving living standards in the longer term) appears more likely to destroy jobs than to create jobs across East Asia Pacific countries over the past three years. This can be due to more productive firms (measured here as a firm's total annual sales divided by its number of employees) conducting their business in a more efficient way that requires fewer workers to produce an equivalent amount of goods or services. This negative relationship may also be explained in part by the majority of firms employing less than 15 workers in nearly all countries in the region (Table 2), while descriptive analysis here indicates that larger firms generally experience higher levels of productivity across the region ${ }^{18}$. 
Similar to wages, it is worth noting that the overall negative relationship observed between productivity and employment reflects firm dynamics over a three year period, while it is possible that higher productivity may possibly lead in some firms-e.g. through a larger production line, new products or markets-to job creation in the longer term. That is, there is the potential for the shorter-term trade-off between job creation and productivity to be offset in the longer term as greater productivity can raise income levels, which in turn can contribute to the expansion of other economic activities and can absorb the slack of labour.

Exporting is positively and significantly correlated with a firm's expansion, especially in larger economies such as China, Indonesia, Mongolia, the Philippines and Vietnam. These results here are in line with findings in sub-Saharan Africa (Fox and Oviedo 2008) and globally (Dutz et al. 2011; Shi and Michelitsch 2012). Yet exporting appears to have no statistically significant relationship within Pacific Island countries (Table 3). Being small and remote, Pacific Island countries can be more constrained in benefiting from agglomeration and are less connected to global trade. The export premium observed especially in larger economies can be associated with potentially greater learning related to working with providers and suppliers in international markets, i.e. possibly acquiring new technical and managerial skills and applying new technologies from abroad (Rankin et al. 2006; World Bank 2012; Movahedi and Gaussens 2012).

Firms in four countries in the region (Fiji, Mongolia, the Philippines and Vanuatu) appeared to still overall expand their firm size despite experiencing, on average, three or more power outages a month (for similar results across sub-Saharan Africa, see Aterido and Hallward-Driemeier 2008). A lack of reliable electricity infrastructure does not seem to have translated into an inevitable binding constraint to firm expansion, with some firms addressing the problem of power outages with their own generators, which about $25 \%$ or more of firms own or share in these four countries (see Table 2 on descriptive statistics). On the other hand, three or more power outages a month appear to significantly constrain firm growth in some countries in which firms have lower levels of generator ownership such as Laos (at about 12\% ownership) and Samoa (at about $19 \%$ ownership).

Firms spending $5 \%$ or more of senior management's time in a typical week dealing with government regulations (taxes, customs, labour regulations, licensing and registration) does not appear to be a very clear or strong correlate of job creation.

Firms' expansion in China, Laos, the Philippines, Tonga and Vietnam seems to have significantly benefited from having a credit line or loan from a bank ${ }^{19}$, as it can improve their capacity to plan longer term and make investments. In Indonesia, however, this relationship was inverse and significant. This could possibly be related to very low levels of credit being the norm in Indonesia, as the country has the second lowest share of firms in the region with a credit line or loan at about $18 \%$ and the lowest share of firms in the region with a checking or savings account at about $50 \%$ (see Table 2). At the same time however, it is possible that in some cases potential influences on this specific indicator could go in both direction, as firms that are growing may possibly be more likely to qualify for, and thus have, a loan from a bank.

In terms of paying bribes, firms are asked if similar establishments are known to make any informal payments to public officials to operate whether for customs, taxes, licenses, regulations, services or the like, which helps mitigate downward bias 
in reporting bribes given potential social and legal stigma associated with direct reporting. Descriptive data illustrate that about $90 \%$ of firms in the region report not having to pay any bribes. Yet, since giving public officials payments has a relatively strong, positive correlation with job growth in several countries in the region, bribes do not appear to present a pressing constraint to creating jobs for many firms. In Vanuatu, however, paying bribes has a negative and significant correlation with job growth, although only $3.4 \%$ of firms reported such payments (see Table 2).

\subsection{Regression model 2 and results}

The following exercise consists of estimating a similar equation, controlling for the same indicators as the first model (Table 3), but the second model also includes information on whether a firm is government owned, uses email, has an external auditor, has an overdraft facility on their bank account, and was inspected by tax officials (Table 4). Estimating these models separately allows for robustness checks and to test the degree to which some of the control variables may be correlated with each other and move in unison. An example is that the second model includes a variable on email use (which often depends on the quality of electricity supply), but the correlates for power outages remain overall similar in both models. Similarly, the second model includes a variable for whether firms were inspected by tax officials (which could influence the prevalence of having to pay bribes), but the correlates for paying informal payments to officials remain overall consistent within both models.

The inclusion of a control for being a government owned firm, although not significant across all countries in the region, shows that private owned firms were more likely to grow (except in Tonga where the public sector is a large employer) ${ }^{20}$. Internet use is an enterprise trait that can be important at various business levels from spreading ideas and innovating to greater employment growth (World Bank 2004; Dutz et al. 2011). Across East Asia Pacific, using email to conduct business has a statistically significant and positive correlation with employment growth in six countries but a negative correlation in Fiji and Mongolia-two countries that are relatively less connected to international markets.

If a firm had its annual financial statement checked and certified by an external auditor last fiscal year, this could be a proxy for better planning, managing and operating their business, with results showing that such firms were overall more likely to have expanded, although this relationship was not always strong. Similar to a credit line or loan, firms with an overdraft facility on their bank account (which already captures having a bank account) more often create jobs, likely as overdraft protection can help to smooth business cycle fluctuations. Firms that reported being inspected by tax officials over the last year were significantly more likely to expand their business operations in China, Fiji, Indonesia, Micronesia, Timor-Leste and Vanuatu. This can be because tax inspection can be a proxy for a core component of a functioning regulatory and tax system, but the same system has the potential to also strain at times some firms with excessive time needed to deal with regulations and with requiring bribes.

\subsection{Exploring variations in the results among sub-samples of firms, and conducting robustness checks}

Estimations of various sub-samples, while verifying on a whole the results, show nonlinearities in the correlates of overall business climate conditions by firm size, firm age, 
and sector of activity, with different types of firms responding at times differently to the same (or similar) business environment. They also reinforce the need for disaggregated analysis. Given smaller sample sizes for such disaggregated analysis and thus reduced variation, several Pacific Island countries had to be omitted from these split regressions and for the remaining countries significance levels were generally slightly lower than in the full second model. The overall negative relationship between productivity and job growth reduces among smaller and younger firms in some countries. In estimating the correlates for the sub-sample of micro firms only (with 5 or fewer employees) using the second model, a few important differences emerge: Higher levels of productivity were strongly correlated with increased job creation in the Philippines and Tonga, and slightly correlated in China; and micro firms with an overdraft facility on their bank account were much more likely to create jobs in the Philippines, Tonga and Vietnam. Pagés et al. (2007) similarly find that improved access to credit can increase employment growth, especially for smaller firms, and can thus help them transition into medium-size or large firms. In a firm age split model including only firms less than 10 years old using the same controls in the second model, one interesting difference is that younger firms with higher productivity were more likely to grow in the Philippines and Mongolia.

In analysing only manufacturing firms using the second model, overall results remain similar between manufacturing and non-manufacturing firms with a few exceptions: Filipino manufacturing firms in large cities or the capital seem to have grown faster than firms in other sectors in these areas; manufacturing firms, with higher shares of females seem to have grown faster in Mongolia and Tonga; and Mongolian manufacturing firms with higher productivity appear to have experienced significant and positive growth. In analysing only service sector firms, overall results are similar, although two differences were that service sector firms were less likely to hire more employees if they were foreign-owned in Indonesia and Mongolia, and if they had three or more power outages per month in Mongolia.

In the following, the second model is tested with pooled data, which is the most common approach in analysing job growth with enterprise survey data in spite of the associated limitations as outlined in the introduction. The country-specific analyses conducted in this paper help circumvent these limitations and can provide policymakers with information relevant for individual countries, while pooled regression analysis instead merges all variation observed across countries in Tables 3 and 4 into a single, averaged estimated coefficient. Nonetheless, in a pooled regression, as a robustness check, including all firm observations across East Asia Pacific (for all 12 countries with data) and including country fixed effects using the second model, the resultswhile largely shaped by conditions in China-show some similar overall trends on some of the correlates of employment growth: firms that grew most are more likely smaller, exporting and foreign-owned, and have lower wages and lower productivity ${ }^{21}$. Yet the regional results hide correlates of job growth that are unique not only within individual countries but also across sub-groups of countries. For example, job creation is overall strongly correlated with service sector firms in the group of Pacific Island countries, while being foreign-owned or exporting has a positive and statistically significant correlation with firm expansion in the group of larger economies in the region including China, Indonesia, the Philippines and Vietnam (in contrast to Pacific Island countries). 
In addition, a probit model is created with job creation as the dependent variable ( 1 or 0 ) and a separate probit model with job destruction as the dependent variable (1 or 0 ), which is in contrast to the average annualised job growth rate of firms as in the previous models. Results suggest that smaller firms are more likely the largest contributor to job creation, while larger firms are the largest contributor to job destruction in the region. However, small firms create and shed most jobs at the global level (World Bank 2012). Government-owned firms are not only less likely to create jobs but are also more likely to shed jobs, especially when China is withdrawn from the regional sample, so that job creation at the regional level appears to be largely private-sector led and particularly strong among foreign-owned firms. Higher wages not only likely deter creating new jobs but also likely support shedding jobs. Results suggest that credit not only supports job growth but also may function as a possible financial shock absorber to mitigate job loss across the region (results for the pooled regressions are in Table 5 in the Appendix for interested readers).

To reiterate, when analysing enterprise survey data, no causal relationships can be established between job creation and the range of business climate indicators irrespective of the statistical model employed, as all models have unobservables (as outlined earlier) that can interact with independent variables and cannot all be fully controlled for $^{22}$. While strong differences arise across countries and sub-groups of countries and while it is likely that the strength of correlates over the past three years will not be identical over the coming years, the country-specific analyses nonetheless can help identify some trends and illustrate that firms within many East Asian and Pacific countries with the following traits grew over this period:

\section{Most job creation}

- Micro and small-sized firms/Firms with lower wages/Exporting firms/Foreignowned firms/Firms with a credit line or loan, and those with an overdraft facility

Least job creation

- Large firms/Sole proprietorships/Firms with higher wages/Government-owned firms/Firms spending $5+\%$ of time on regulations/Firms with higher levels of productivity

In general, results suggest that an overall weak business climate in a number of countries in the region can help sustain the distribution of enterprises towards smaller firms. Also, given that most job growth was experienced by small firms, which are generally more labour-intensive and less productive, this could raise concerns in the longer term about the efficient allocation of resources and aggregate productivity growth.

\section{Conclusion and policy implications}

This paper aims to, first, reduce a research gap on the correlates of job growth by analysing each country individually with enterprise surveys within all 12 East Asian and Pacific countries with data between 2009 and 2012, while analysing, second, a much broader range of firm-level factors simultaneously than currently in the enterprise survey literature. These combined are the main contributions of this paper to the literature on job growth, while also being more clear and transparent in outlining the strong limits of analysing enterprise survey data, especially in terms of not being able to 
identify causal effects of job growth that most existing studies neglect to acknowledge. The results here, while recognising the many limitations such as those related to omitted variables and small survey samples in some countries, can nonetheless help provide some insights into the correlates of job creation across East Asia Pacific and provide useful information to inform policymakers.

Yet most existing papers that use enterprise survey data apply pooled, crosscountry regression in analysing job growth and thus assume that correlates of job growth would be similar across countries. This paper illustrates that this assumption does not hold strongly across many variables and countries, and it outlines several important limitations of this standard approach. It argues to shift away from this popular approach towards country-level analyses which can generally provide more nuance and greater relevance for individual policymakers.

In conducting multivariate econometric analyses at the country level, this paper identifies a number of factors which vary across countries and which firm owners and policymakers may need to consider in efforts to help create jobs within each individual country. While laying the fundamentals such as basic infrastructure and financial institutions tends to apply to all countries, the level of importance of other factors needs to be assessed in each individual context and policy planners and implementers may need to consider:

- Not neglecting micro and small firms despite political influence of better organised, larger firms that more often experience low, stagnant or even negative growth

- Widening access to credit

- Weighing potential tradeoffs between the competing objectives of job growth and workers' wage demands (e.g. when considering policies that regulate the level of minimum wage)

- Improving the conditions and ease of exporting

- Promoting the connection of firms to global value chains

- Possibly reducing potential restrictions for foreign-owned firms to operate their businesses

- Standardising business forms and easing procedures to reduce the amount of time firms spend on regulations.

Furthermore, electricity and corruption do not appear to be among the most pressing obstacles to creating jobs across East Asia Pacific countries.

At the same time however, the level of priority of each policy approach will always vary across countries and sub-groups of countries. In adopting policies to tackle potential constraints facing firms, it will be important to also assess government implementation constraints across individual countries, ranging from administrative and technical capacity to financial and political viability. In addition, it is critical for policymakers to weigh competing interests and tradeoffs when considering policies, as policies generally produce both winners and losers. An example is that more excessive firm regulations are adversely correlated with firm growth in many countries in the region, but they 
may possibly positively affect other groups in society that benefit from greater regulations. Another example is that improving export conditions in a country can bring several aggregate benefits but can potentially negatively affect some smaller local firms or, more broadly, the environment through greater transport of products. Furthermore, it would be useful from a policy perspective to combine these results with qualitative and other quantitative results to try and gain a more complete picture of job creation.

In closing, it is important to stress that firms more likely assess government policies and business opportunities as part of a package, rather than in isolation. Targeted policy responses in isolation such as improving financial infrastructure or exporting conditions will likely not lead inevitably to higher employment growth across East Asian and Pacific countries. Creating jobs will most likely require identifying the right mix of multiple policies and reforms in each country that simultaneously aim to improve the broader business, investment and institutional environment.

\section{Endnotes}

${ }^{1}$ For an overview of the literature on job creation, enterprise surveys, and the business climate, see Dethier et al. 2011; World Bank 2004; Sutton 1997.

${ }^{2}$ For example: Ayyagari et al. 2011.

${ }^{3}$ For example: Shi and Michelitsch 2012.

${ }^{4}$ For example: De Elejalde et al. 2011; Dutz et al. 2011.

${ }^{5}$ For example: Djankov et al. 2002; Klapper et al. 2004; Dollar et al. 2005; Fox and Oviedo 2008.

${ }^{6}$ For example: Alby et al. 2011.

${ }^{7}$ For example: Beck et al. 2005; Demirgüç-Kunt and Maksimovic 1998; Rajan and Zingales 1998; Ayyagari et al. 2006; Pagés et al. 2007; Fisman and Svensson 2007.

${ }^{8}$ Cross-country papers using pooled data generally do not control at sub-national levels for all differences in labour conditions, policies and institutions. For this paper, it was possible to include a control variable into the regressions for firm location in a small city, or the capital/city with at least 1 million people.

${ }^{9}$ See for example: Acquisti and Lehmann 1999; Fisman and Svensson 2007; De Elejalde et al. 2011.

${ }^{10}$ Formal (i.e. registered) firms with five or more employees are the target group for interviews, while all interviewed firms are asked if they were formally registered when they started their business, which is included as a control in the regressions.

${ }^{11}$ It is important to bear in mind that those firms have been omitted from the analysis that were not in business three years ago (3.3\% of all firms in the region) and those that were not able to answer the question if they were in business three years ago (1.7\% of all firms). This also helps reduce the upward bias in the results on job creation (caused by firms that closed not being captured) as all of the $3.3 \%$ of firms that started their business within the last three years had by definition positive employment growth (relative to the baseline of zero employees three years ago). Yet this sample of young, emerging firms can provide a reflection of more aggregate emerging trends in the region, with Vietnam and Timor-Leste accounting for much larger shares of these young firms relative to the full sample. These young firms across the region are also more concentrated in the service sector (57.8\% of all of these firms) relative to the full sample 
(40.9\% of firms), suggesting that service sector firms are expanding more rapidly than manufacturing firms in most countries in the region.

${ }^{12}$ To be as transparent as possible not only about the limitations of the survey design but also of the collected data, it is worth mentioning that a number of issues had to be addressed with the data. For example, the survey weights for $1.4 \%$ of the observations for all East Asia Pacific countries since 2009 had to be changed to 1 as they were below 1 which is an error in the applied weighting methods; this is particularly problematic for the Laos 2009 survey (16.4\% of firms with sampling weights $<1$ ) so this paper therefore only uses the Laos 2012 survey. These amended weights are used throughout the entire analysis. Also, some enumerators or respondents for the 2009 survey in Tonga responded incorrectly to the question on the number of employees in their firm three years ago-i.e. instead of stating the number of actual employees working in their firm three years ago they accidentally answered with the year itself (2005 or 2006) three years ago; these data observations have been omitted from the sample.

${ }^{13}$ Also, employment growth is a better indicator to capture firm performance relative to sales growth, because firm sales experience greater volatility, may not always be (fully) reported for tax purposes and are more susceptible to measuring and reporting error when comparing with sales three years ago.

${ }^{14}$ An international study by the World Bank (2004) found that power outages in firms led to losses in their annual sales at about five percent.

${ }^{15}$ This modelling approach of including a broader range of variables in a single model is also reinforced in the World Bank's World Development Report 2005 'A Better Investment Climate for Everyone'.

${ }^{16}$ Some studies claim to better control for levels of endogeneity by creating and using location-sector or location-sector-size averages instead of firms' own responses (e.g. Aterido and Hallward-Driemeier 2008), but they thereby restrict variation across firms and generate the strong assumption that correlates would interact similarly across such averages.

${ }^{17}$ See for example: Evans 1987; Acquisti and Lehmann 1999; Haltiwanger and Milan Vodopivec 2002; Fox and Oviedo 2008; Ayyagari et al. 2011; Shi and Michelitsch 2012.

${ }^{18}$ Larger firms are also often better positioned to gain economies of scale and to undertake greater investments such as in machinery that can enhance productivity.

${ }^{19}$ These findings are found globally as well (Pagés et al. 2007; Aterido and HallwardDriemeier 2008; Dutz et al. 2011).

${ }^{20}$ Similar results are found internationally (Haltiwanger and Milan Vodopivec 2002).

${ }^{21}$ Even in a pooled regression for East Asia Pacific without China, results then become largely shaped by trends in Indonesia given its relatively large survey sample.

${ }^{22}$ There is also the possibility for potential influences going in both directions. That is, better objective firm-level indicators can help improve firm performance and growth, but they can also possibly be in part a result of better performing and growing firms. Such firms may be more likely to relocate to an area with better electricity access or simply have more resources to purchase a generator or make a down payment to open a line of credit, among others. 


\section{Appendix}

Table 4 Correlates of job growth among basic firm-level features and overall business climate traits including wages, infrastructure, regulation and finance, in East Asia Pacific over the last 3 years (model 2)

\begin{tabular}{|c|c|c|c|c|c|c|c|c|c|c|c|c|}
\hline \multirow{2}{*}{$\begin{array}{l}\text { Dependent variable: Job growth } \\
\text { rate, annual }\end{array}$} & \multicolumn{2}{|l|}{ China } & \multicolumn{2}{|l|}{ Fiji } & \multicolumn{2}{|l|}{ Indonesia } & \multicolumn{2}{|l|}{ Lao } & \multicolumn{2}{|c|}{ Micronesia } & \multicolumn{2}{|l|}{ Mongolia } \\
\hline & Coef. & tstat & Coef. & tstat & Coef. & tstat & Coef. & tstat & Coef. & tstat & Coef. & tstat \\
\hline \multicolumn{13}{|l|}{ Basic firm-level traits } \\
\hline Initial firm size, $<=5$ emp. (ref. 31+) & $0.136^{* * *}$ & 195.0 & $0.135^{* * *}$ & 3.7 & $0.358^{* * *}$ & 82.8 & $0.146^{* * *}$ & 5.3 & $0.968^{* * *}$ & 11.4 & $2.362^{* * *}$ & 18.6 \\
\hline Initial firm size, 6-15 emp. & $0.048^{* * *}$ & 106.3 & $0.116^{* * *}$ & 3.7 & $0.060^{* * *}$ & 14.5 & $0.084^{* * *}$ & 3.6 & $0.148^{* * *}$ & 2.9 & $0.572^{* * *}$ & 5.9 \\
\hline Initial firm size, 16-30 emp. & $0.009^{* * *}$ & 16.4 & $0.063^{* *}$ & 2.3 & $-0.017^{* * *}$ & -3.1 & -0.044 & -1.5 & $0.241^{* * *}$ & 4.4 & $0.276^{* * *}$ & 2.9 \\
\hline Firms $<10$ years old (ref. $>=20$ ) & $0.029^{* * *}$ & 42.5 & $0.064^{* *}$ & 2.0 & $0.012^{* * *}$ & 4.8 & 0.027 & 1.2 & $0.096^{*}$ & 1.8 & 0.119 & 0.8 \\
\hline Firms $10-19$ years old & $0.007^{* * *}$ & 10.8 & 0.034 & 1.6 & $0.069^{* * *}$ & 27.6 & -0.003 & -0.1 & $0.195^{* * *}$ & 4.1 & $0.490^{* * *}$ & 3.7 \\
\hline City w/ 1 mil. or capital (ref. small city) & $0.016^{* * *}$ & 8.9 & 0.018 & 0.8 & $-0.052^{* * *}$ & -26.6 & - & - & - & - & $0.239 * * *$ & 3.0 \\
\hline Manufacturing (ref. other sectors) & $0.044^{* * *}$ & 41.4 & 0.064 & 1.3 & $0.026^{* * *}$ & 3.3 & $-0.128^{* * *}$ & -3.4 & -0.053 & -0.6 & $-1.000^{* * *}$ & -10.1 \\
\hline Services & 0.002 & 1.5 & $0.146^{* * *}$ & 4.1 & 0.001 & 0.2 & $-0.120^{* * *}$ & -3.4 & $0.352^{* * *}$ & 4.6 & $-1.213^{* * *}$ & -11.5 \\
\hline Formally registered when opened & $0.005^{* * *}$ & 6.5 & 0.054 & 1.3 & $-0.020^{* * *}$ & -7.9 & $-0.034^{*}$ & -1.7 & $0.624^{* * *}$ & 5.8 & 0.115 & 1.0 \\
\hline Sole proprietorship & $-0.011^{* * *}$ & -32.5 & -0.009 & -0.5 & $-0.166^{* * *}$ & -52.6 & 0.008 & 0.2 & $-0.216^{* * *}$ & -5.3 & 0.132 & 0.5 \\
\hline Firm is foreign owned, partly or fully & $0.016^{* * *}$ & 18.9 & 0.009 & 0.3 & $0.093^{* * *}$ & 11.6 & $0.062^{*}$ & 1.8 & $0.117^{* *}$ & 2.7 & 0.029 & 0.3 \\
\hline Firm is partly government owned & $-0.003 * * *$ & -3.4 & - & - & -0.084 & -1.1 & - & - & - & - & -0.120 & -0.1 \\
\hline Share of female employees & $-0.046^{* * *}$ & -55.5 & $-0.147^{* * *}$ & -5.5 & $-0.071^{* * *}$ & -26.3 & $-0.087^{* * *}$ & -3.2 & $-0.582^{* * *}$ & -6.2 & $-0.544^{* * *}$ & -4.1 \\
\hline \multicolumn{13}{|l|}{ Wage and productivity traits } \\
\hline Wage per worker, tercile 2 (ref. ter. 1 ) & $0.025^{* * *}$ & 55.4 & $-0.082^{* * *}$ & -3.1 & $-0.110^{* * *}$ & -47.9 & $-0.047^{* *}$ & -2.4 & $-0.481^{* * *}$ & -7.1 & $-0.259 * * *$ & -3.3 \\
\hline Wage per worker, tercile 3 & $0.014^{* * *}$ & 30.4 & 0.009 & 0.3 & $-0.109^{* * *}$ & -32.0 & $-0.055^{* * *}$ & -2.8 & $-0.470^{* * *}$ & -6.3 & $-0.493 * * *$ & -5.5 \\
\hline Labour productivity (sales/employ.), In & $-0.008^{* * *}$ & -50.3 & $-0.066^{* * *}$ & -9.8 & $-0.006^{* * *}$ & -6.3 & -0.007 & -1.2 & $0.074^{* * *}$ & 3.3 & 0.019 & 0.7 \\
\hline \multicolumn{13}{|l|}{ Technology and infrastructure traits } \\
\hline Firm exports & $0.021^{* * *}$ & 37.5 & $0.067^{*}$ & 1.7 & $0.185^{* * *}$ & 28.9 & 0.021 & 0.9 & - & - & $0.335^{* * *}$ & 2.6 \\
\hline Email use for doing business & $0.007^{* * *}$ & 14.7 & $-0.102^{* * *}$ & -2.6 & $-0.050^{* * *}$ & -14.0 & $0.084^{* * *}$ & 4.5 & -0.027 & -0.4 & $-0.373 * * *$ & -4.4 \\
\hline Has 3 or + power outages a month & - & - & $0.118^{* * *}$ & 4.9 & - & - & -0.024 & -1.5 & $0.084^{*}$ & 1.8 & $0.739^{* * *}$ & 10.9 \\
\hline \multicolumn{13}{|l|}{ Business regulation traits } \\
\hline Firm has ISO certification & $-0.026^{* * *}$ & -69.8 & $-0.128^{* * *}$ & -5.1 & $-0.025^{* * *}$ & -4.0 & $-0.105^{* * *}$ & -4.2 & 0.001 & 0.0 & $-0.306^{* * *}$ & -3.3 \\
\hline Firm has external auditor & $0.023^{* * *}$ & 63.6 & 0.010 & 0.3 & -0.001 & -0.2 & $0.055^{* * *}$ & 3.1 & -0.028 & -0.7 & $0.157^{*}$ & 1.7 \\
\hline Spends $5+\%$ of time w/regulations & $0.036^{* * *}$ & 51.0 & $-0.046^{* *}$ & -2.4 & $-0.016^{* * *}$ & -5.4 & $0.050^{* * *}$ & 2.9 & $-0.109^{* *}$ & -2.1 & $-0.220^{* * *}$ & -3.1 \\
\hline \multicolumn{13}{|l|}{ Financial climate traits } \\
\hline Has credit line or loan from a bank & $0.025^{* * *}$ & 55.8 & $-0.094^{* * *}$ & -3.3 & $-0.020^{* * *}$ & -8.1 & $0.080^{* * *}$ & 4.5 & $0.083^{*}$ & 1.8 & -0.013 & -0.2 \\
\hline Has overdraft facility with their bank & $0.002^{* * *}$ & 4.9 & $0.082^{* * *}$ & 4.1 & 0.007 & 1.4 & - & - & $-0.253^{* * *}$ & -4.4 & $0.425^{* * *}$ & 6.4 \\
\hline \multicolumn{13}{|l|}{ Tax and corruption traits } \\
\hline Inspected by tax officials last year & $0.004^{* * *}$ & 10.2 & $0.096^{* * *}$ & 4.7 & $0.020^{* * *}$ & 6.1 & $-0.088^{* *}$ & -2.5 & $0.272^{* * *}$ & 5.5 & 0.051 & 0.7 \\
\hline Gives informal payments to officials & $-0.064 * * *$ & -66.5 & $-0.105 * *$ & -2.4 & $0.084^{* * *}$ & 24.1 & & - & & - & & - \\
\hline $\begin{array}{l}\text { Constant } \\
\text { Observations }\end{array}$ & $0.081^{* * *}$ & 27.0 & $0.625^{* * *}$ & 5.8 & $0.268^{* * *}$ & 14.9 & $0.280^{* *}$ & 2.3 & $-1.282^{* * *}$ & -4.6 & 0.213 & 0.5 \\
\hline $\begin{array}{l}\text { Observations } \\
\text { Adjusted R-squared }\end{array}$ & $\begin{array}{l}1678 \\
0.139\end{array}$ & & $\begin{array}{l}45 \\
0.565\end{array}$ & & $\begin{array}{l}837 \\
0.186\end{array}$ & & $\begin{array}{l}159 \\
0.265\end{array}$ & & $\begin{array}{l}32 \\
0.929\end{array}$ & & $\begin{array}{l}171 \\
0.503\end{array}$ & \\
\hline
\end{tabular}


Table 4 Correlates of job growth among basic firm-level features and overall business climate traits including wages, infrastructure, regulation and finance, in East Asia Pacific over the last 3 years (model 2) (Continued)

\begin{tabular}{|c|c|c|c|c|c|c|c|c|c|c|c|c|}
\hline \multirow{2}{*}{$\begin{array}{l}\text { Dependent variable: Job growth } \\
\text { rate, annual }\end{array}$} & \multicolumn{2}{|c|}{ Philippines } & \multicolumn{2}{|l|}{ Samoa } & \multicolumn{2}{|c|}{ Timor-Leste } & \multicolumn{2}{|l|}{ Tonga } & \multicolumn{2}{|l|}{ Vanuatu } & \multicolumn{2}{|l|}{ Vietnam } \\
\hline & Coef. & tstat & Coef. & tstat & Coef. & tstat & Coef. & tstat & Coef. & tstat & Coef. & tstat \\
\hline \multicolumn{13}{|l|}{ Basic firm-level traits } \\
\hline Initial firm size, $<=5$ emp. (ref. 31+) & $0.379^{* * *}$ & 26.9 & $0.212^{* * *}$ & 3.8 & $0.262^{* *}$ & 2.5 & $0.136 * *$ & 3.5 & 0.043 & 0.3 & $0.511^{* * *}$ & 23.8 \\
\hline Initial firm size, 6-15 emp. & $0.090^{* * *}$ & 9.3 & -0.005 & -0.1 & $0.270^{* * *}$ & 3.0 & $0.098^{* *}$ & 2.5 & 0.058 & 0.7 & $0.533^{* * *}$ & 32.5 \\
\hline Initial firm size, 16-30 emp. & $0.066^{* * *}$ & 6.7 & -0.041 & -0.5 & -0.004 & -0.0 & -0.000 & -0.0 & 0.111 & 1.1 & $0.224^{* * *}$ & 13.5 \\
\hline Firms $<10$ years old (ref. $>=20$ ) & $-0.084^{* * *}$ & -8.5 & -0.030 & -0.6 & -0.171 & -0.6 & $0.024^{*}$ & 1.9 & $0.241 * * *$ & 3.3 & $-0.079 * * *$ & -3.5 \\
\hline Firms $10-19$ years old & $-0.077^{* * *}$ & -8.9 & $-0.121^{* * *}$ & -3.0 & -0.060 & -0.2 & 0.013 & 0.9 & $0.136^{*}$ & 1.8 & 0.017 & 0.8 \\
\hline City w/ 1 mil. or capital (ref. small city) & $-0.023^{* * *}$ & -2.8 & -0.118 & -1.3 & - & - & - & - & - & - & $0.090^{* * *}$ & 6.1 \\
\hline Manufacturing (ref. other sectors) & 0.029 & 0.8 & -0.051 & -1.0 & $-0.160^{* *}$ & -2.0 & $0.112^{* * *}$ & 8.8 & -0.140 & -1.1 & $-0.118^{* * *}$ & -5.8 \\
\hline Services & $0.076^{* *}$ & 2.0 & -0.031 & -0.6 & -0.095 & -1.1 & & & 0.051 & 0.6 & $-0.252^{* * *}$ & -11.7 \\
\hline Formally registered when opened & $0.117^{* * *}$ & 5.9 & -0.039 & -0.7 & -0.077 & -0.8 & $0.067^{* * *}$ & 3.2 & -0.000 & -0.0 & $0.191 * * *$ & 12.6 \\
\hline Sole proprietorship & $-0.017^{*}$ & -1.7 & -0.037 & -1.1 & -0.089 & -1.1 & -0.025 & -1.6 & $0.177^{* *}$ & 2.6 & $-0.156^{* * *}$ & -12.9 \\
\hline Firm is foreign owned, partly or fully & $0.044^{* * *}$ & 4.1 & 0.054 & 1.4 & 0.033 & 0.5 & $-0.059^{* * *}$ & -3.7 & -0.050 & -0.8 & -0.002 & -0.1 \\
\hline Firm is partly government owned & -0.025 & -0.7 & $-0.269^{* * *}$ & -2.7 & & - & 0.058 & 1.2 & & - & $-0.132^{* * *}$ & -4.8 \\
\hline Share of female employees & $-0.120^{* * *}$ & -8.5 & $0.206^{* * *}$ & 3.6 & $-0.239^{*}$ & -1.7 & $-0.104^{* * *}$ & -4.7 & -0.144 & -1.3 & $0.081^{* * *}$ & 3.7 \\
\hline \multicolumn{13}{|l|}{ Wage and productivity traits } \\
\hline Wage per worker, tercile 2 (ref. ter. 1) & $-0.067^{* * *}$ & -6.7 & -0.051 & -1.6 & $-0.119^{*}$ & -1.8 & $-0.029^{* *}$ & -2.4 & -0.009 & -0.1 & $-0.156^{* * *}$ & -10.9 \\
\hline Wage per worker, tercile 3 & $-0.061^{* * *}$ & -5.4 & $-0.232^{* * *}$ & -6.2 & $-0.170^{* *}$ & -2.2 & $-0.047^{* * *}$ & -3.7 & $-0.161^{* *}$ & -2.1 & $-0.306^{* * *}$ & -20.5 \\
\hline Labour productivity (sales/employ.), In & $-0.011^{* * *}$ & -3.9 & $-0.024^{* *}$ & -2.1 & 0.012 & 0.8 & $-0.026^{* * *}$ & -5.0 & -0.043 & -1.6 & $-0.018^{* * *}$ & -3.5 \\
\hline \multicolumn{13}{|l|}{ Technology and infrastructure traits } \\
\hline Firm exports & $0.042^{* * *}$ & 3.4 & -0.037 & -0.9 & -0.175 & -1.0 & 0.016 & 0.5 & - & - & 0.023 & 1.5 \\
\hline Email use for doing business & $0.077^{* * *}$ & 7.4 & 0.047 & 1.0 & $0.135^{* *}$ & 2.1 & $0.018^{*}$ & 1.8 & $0.254^{* *}$ & 2.1 & -0.012 & -0.8 \\
\hline Has 3 or + power outages a month & $0.085^{* * *}$ & 7.8 & $-0.196^{* * *}$ & -5.3 & - & - & 0.016 & 1.4 & $0.197^{* * *}$ & 2.7 & $-0.085^{* * *}$ & -7.5 \\
\hline \multicolumn{13}{|l|}{ Business regulation traits } \\
\hline Firm has ISO certification & $0.036^{* * *}$ & 3.5 & $0.116^{* *}$ & 2.5 & $-0.483^{* *}$ & -2.2 & -0.013 & -0.9 & 0.040 & 0.6 & $0.055^{* * *}$ & 3.1 \\
\hline Firm has external auditor & $-0.048^{* * *}$ & -3.6 & $-0.261^{* * *}$ & -6.4 & 0.050 & 0.7 & 0.007 & 0.6 & $0.116^{*}$ & 1.8 & $0.192^{* * *}$ & 14.0 \\
\hline \multirow{2}{*}{\multicolumn{13}{|c|}{ Financial climate traits }} \\
\hline & & & & & & & & & & & & \\
\hline Has overdraft facility with their bank & $0.065^{* * *}$ & 7.7 & $-0.063^{*}$ & -1.9 & $0.123^{*}$ & 1.7 & 0.003 & 0.2 & 0.093 & 1.2 & $-0.162^{* * *}$ & -10.6 \\
\hline \multicolumn{13}{|l|}{ Tax and corruption traits } \\
\hline Inspected by tax officials last year & $-0.064^{* * *}$ & -6.1 & $-0.103^{* *}$ & -2.6 & $0.125^{* *}$ & 2.1 & -0.015 & -1.2 & $0.202^{* *}$ & 2.5 & 0.003 & 0.2 \\
\hline Gives informal payments to officials & 0.007 & 0.9 & $0.139^{* * * *}$ & 3.3 & 0.071 & 0.8 & $0.202^{* * *}$ & 3.0 & -0.233 & -1.1 & $0.033^{* *}$ & 2.4 \\
\hline $\begin{array}{l}\text { Constant } \\
\text { Observations }\end{array}$ & $\begin{array}{l}0.051 \\
473\end{array}$ & 0.9 & $\begin{array}{l}0.964^{* * *} \\
41\end{array}$ & 6.0 & $\begin{array}{l}0.181 \\
60\end{array}$ & 0.6 & $\begin{array}{l}0.161^{* *} \\
70\end{array}$ & 2.4 & $\begin{array}{l}-0.050 \\
58\end{array}$ & -0.1 & $\begin{array}{l}0.403^{* * *} \\
348\end{array}$ & 4.1 \\
\hline Adjusted R-squared & 0.117 & & 0.738 & & 0.339 & & 0.437 & & 0.372 & & 0.217 & \\
\hline
\end{tabular}

Source: Author's regression results based on calculations of enterprise survey data. Note: The same note applies as in Table 3. 
Table 5 Correlates of job growth, job creation and job destruction among basic firm-level features and overall business climate traits, East Asia Pacific average over the last 3 years (model 3 )

\begin{tabular}{|c|c|c|c|c|c|c|c|c|c|c|c|c|}
\hline \multirow{4}{*}{ Dependent variable: } & \multicolumn{6}{|c|}{ East Asia Pacific without China } & \multicolumn{6}{|c|}{ East Asia Pacific with China } \\
\hline & \multicolumn{2}{|c|}{ Job growth rate, annual } & \multicolumn{2}{|c|}{ Job creation } & \multicolumn{2}{|c|}{ Job destruction } & \multicolumn{2}{|c|}{ Job growth rate, annual } & \multicolumn{2}{|c|}{ Job creation } & \multicolumn{2}{|c|}{ Job destruction } \\
\hline & \multicolumn{2}{|l|}{$\overline{(\%)}$} & \multicolumn{2}{|l|}{$(1$ or 0$)$} & \multicolumn{2}{|l|}{$(1$ or 0$)$} & \multicolumn{2}{|l|}{$(\%)$} & \multicolumn{2}{|l|}{$(1$ or 0$)$} & \multicolumn{2}{|l|}{$(1$ or 0$)$} \\
\hline & Coef. & tstat & Coef. & tstat & Coef. & tstat & Coef. & tstat & Coef. & tstat & Coef. & tstat \\
\hline \multicolumn{13}{|l|}{ Basic firm-level traits } \\
\hline Initial firm size, $<=5$ emp. (ref. $31+$ ) & $0.517^{* * *}$ & 110.4 & $0.656^{* * *}$ & 135.4 & $-0.557^{* * *}$ & -121.6 & $0.389^{* * *}$ & 204.3 & $0.453^{* * *}$ & 149.3 & $-0.358^{* * *}$ & -160.4 \\
\hline Initial firm size, 6-15 emp. & $0.151^{* * *}$ & 35.0 & $0.083^{* * *}$ & 18.6 & $-0.203^{* * *}$ & -48.0 & $0.061^{* * *}$ & 43.4 & $-0.021 * * *$ & -9.4 & $-0.087^{* * *}$ & -52.2 \\
\hline Initial firm size, 16-30 emp. & $0.067^{* * *}$ & 12.7 & $-0.022 * * *$ & -4.0 & $-0.062^{* * *}$ & -12.0 & $0.013^{* * *}$ & 7.6 & $-0.062^{* * *}$ & -22.0 & $-0.018^{* * *}$ & -8.6 \\
\hline Firms $<10$ years old (ref. $>=20$ ) & $-0.034^{* * *}$ & -10.4 & $0.119^{* * *}$ & 35.1 & $0.036^{* * *}$ & 11.3 & $0.017^{* * *}$ & 11.6 & $0.179^{* * * *}$ & 76.7 & $-0.044^{* * *}$ & -25.9 \\
\hline Firms $10-19$ years old & 0.004 & 1.1 & $0.021^{* * *}$ & 6.2 & $0.036^{* * *}$ & 11.5 & $0.025^{* * *}$ & 17.9 & $0.199^{* * *}$ & 87.7 & $-0.032^{* * *}$ & -19.2 \\
\hline City w/ 1 mil. or capital (ref. small city) & $0.005^{* *}$ & 2.0 & $-0.124^{* * *}$ & -47.8 & $0.053^{* * *}$ & 21.7 & $0.015^{* * *}$ & 9.3 & $-0.120^{* * *}$ & -47.3 & $0.056^{* * *}$ & 30.1 \\
\hline Manufacturing (ref. other sectors) & $-0.031^{* * *}$ & -4.1 & $-0.057^{* * *}$ & -7.4 & $0.072^{* * *}$ & 9.8 & $0.045^{* * *}$ & 16.2 & $0.164^{* * *}$ & 36.5 & $-0.172^{* * *}$ & -52.3 \\
\hline Services & $-0.068^{* * *}$ & -8.9 & $-0.084^{* * *}$ & -10.6 & $-0.020^{* * *}$ & -2.7 & $0.032^{* * *}$ & 11.3 & $0.170^{* * *}$ & 37.7 & $-0.174^{* * *}$ & -52.5 \\
\hline Formally registered when opened & $0.023^{* * *}$ & 6.9 & $0.029^{* * *}$ & 8.4 & 0.003 & 1.0 & $0.003^{* *}$ & 2.1 & $-0.042^{* * *}$ & -18.0 & $-0.032^{* * *}$ & -18.6 \\
\hline Sole proprietorship & $-0.174^{* * *}$ & -50.1 & $-0.029^{* * *}$ & -8.1 & $-0.070^{* * *}$ & -20.8 & $-0.038^{* * *}$ & -34.1 & $-0.053^{* * *}$ & -29.2 & $-0.039^{* * *}$ & -29.7 \\
\hline Firm is foreign owned, partly or fully & $0.056^{* * *}$ & 7.6 & $0.237^{* * *}$ & 31.3 & $-0.070^{* * *}$ & -9.7 & $0.017^{* * *}$ & 7.4 & $0.140^{* * *}$ & 38.2 & $-0.022^{* * *}$ & -8.3 \\
\hline Firm is partly government owned & $-0.133^{* * *}$ & -8.7 & $-0.065^{* * *}$ & -4.1 & $0.129^{* * *}$ & 8.6 & $-0.024^{* * *}$ & -4.5 & $0.050^{* * *}$ & 5.8 & $0.016^{* *}$ & 2.6 \\
\hline Share of female employees & $-0.055^{* * *}$ & -14.8 & $-0.021^{* * *}$ & -5.6 & $-0.075^{* * *}$ & -20.6 & $-0.050^{* * *}$ & -27.1 & $-0.090^{* * *}$ & -30.2 & $-0.060^{* * *}$ & -27.4 \\
\hline \multicolumn{13}{|l|}{ Wage and productivity traits } \\
\hline Wage per worker, tercile 2 (ref. ter. 1) & $-0.082^{* * *}$ & -10.4 & $-0.308^{* * *}$ & -37.9 & $0.149^{* * *}$ & 19.4 & $-0.015^{* * *}$ & -11.4 & $0.040^{* * *}$ & 18.6 & $-0.006^{* * *}$ & -3.5 \\
\hline Wage per worker, tercile 3 & $-0.171^{* * *}$ & -20.0 & $-0.409^{* * *}$ & -46.1 & $0.209^{* * *}$ & 24.9 & $-0.075^{* * *}$ & -22.9 & $-0.112^{* * *}$ & -21.3 & $0.208^{* * *}$ & 53.6 \\
\hline Labour productivity (sales/employ.), In & $-0.013^{* * *}$ & -11.3 & $-0.005^{* * *}$ & -4.0 & $-0.005^{* * *}$ & -4.7 & $-0.015^{* * *}$ & -30.9 & $-0.026^{* * *}$ & -34.3 & $-0.016^{* * *}$ & -28.3 \\
\hline $\begin{array}{l}\text { Technology and infrastructure traits } \\
\text { Firm exports }\end{array}$ & $0.097 * * *$ & 177 & & & & & & & & & $0.061^{* * *}$ & \\
\hline $\begin{array}{l}\text { Firm exports } \\
\text { Email use for doing business }\end{array}$ & $-0.032 * * *$ & -8.3 & $0.074^{* * *}$ & $\begin{array}{l}2.4 \\
18.7\end{array}$ & $\begin{array}{l}-0.075^{* * *} \\
-0.086^{* * *}\end{array}$ & $\begin{array}{l}-14.0 \\
-23.0\end{array}$ & $\begin{array}{l}0.004^{* *} \\
0.020^{* * *}\end{array}$ & $\begin{array}{l}2.3 \\
14.1\end{array}$ & $\begin{array}{l}-0.075^{* * *} \\
0.157^{* * * *}\end{array}$ & $\begin{array}{l}-26.9 \\
694\end{array}$ & $\begin{array}{l}0.0611^{* * *} \\
-0.0 * 2^{* * *}\end{array}$ & $\begin{array}{l}30.1 \\
-71\end{array}$ \\
\hline Has 3 or + power outages a month & $0.048^{* * *}$ & 16.4 & $0.016^{* * *}$ & 5.2 & $0.033^{* * *}$ & 11.6 & $0.052^{* * *}$ & 29.0 & $-0.024^{* * *}$ & -8.2 & $0.045^{* * *}$ & 21.0 \\
\hline \multicolumn{13}{|l|}{ Business regulation traits } \\
\hline Firm has ISO certification & $0.012^{* *}$ & 2.1 & 0.005 & 0.8 & $0.093^{* * *}$ & 16.5 & $0.028^{* * *}$ & 21.5 & $0.004^{*}$ & 1.7 & $-0.011^{* * *}$ & -7.0 \\
\hline Firm has external auditor & $0.009^{*}$ & 1.8 & $0.093^{* * *}$ & 18.8 & $-0.130^{* * *}$ & -27.9 & $0.033^{* * *}$ & 25.8 & $0.055^{* * *}$ & 27.2 & $-0.032^{* * *}$ & -21.1 \\
\hline Spends $5+\%$ of time $w /$ regulations & $-0.034^{* * *}$ & -10.0 & $0.009^{* *}$ & 2.6 & $-0.060^{* * *}$ & -18.5 & $-0.004^{* * *}$ & -2.7 & $-0.026^{* * *}$ & -10.4 & $-0.050^{* * *}$ & -27.7 \\
\hline \multicolumn{13}{|l|}{ Financial climate traits } \\
\hline Has credit line or loan from a bank & $0.045^{* * *}$ & 14.9 & $0.175^{* * *}$ & 56.1 & $-0.063^{* * *}$ & -21.3 & $0.006^{* * *}$ & 4.7 & $0.079^{* * *}$ & 39.2 & $-0.009^{* * *}$ & -6.1 \\
\hline Has overdraft facility with their bank & $0.036^{* * *}$ & 7.7 & $0.091 * *$ & 19.0 & $-0.061 * * *$ & -13.6 & $0.007^{* * *}$ & 5.6 & $0.007^{* * *}$ & 3.5 & $-0.024^{* * *}$ & -15.9 \\
\hline \multicolumn{13}{|l|}{ Tax and corruption traits } \\
\hline Inspected by tax officials last year & $-0.023^{* * *}$ & -6.4 & $-0.043^{* * *}$ & -11.5 & $0.025^{* * *}$ & 7.1 & $-0.012^{* * *}$ & -9.5 & $0.061^{* * *}$ & 29.7 & $-0.035^{* * *}$ & -23.5 \\
\hline $\begin{array}{l}\text { Gives informal payments to officials } \\
\text { Country fixed effects }\end{array}$ & $\begin{array}{l}0.118^{* * *} \\
\text { yes }\end{array}$ & 30.7 & $\begin{array}{l}0.009^{* *} \\
\text { yes }\end{array}$ & 2.3 & $\begin{array}{l}-0.064^{* * *} \\
\text { yes }\end{array}$ & -17.0 & $\begin{array}{l}0.064^{* * *} \\
\text { yes }\end{array}$ & 33.3 & $\begin{array}{l}-0.049^{* * *} \\
\text { yes }\end{array}$ & -15.6 & $\begin{array}{l}0.007^{* * *} \\
\text { yes }\end{array}$ & 3.3 \\
\hline Constant & $0.279^{* *}$ & 2.1 & $0.859^{* * *}$ & 6.4 & $0.453^{* * *}$ & 3.6 & 0.097 & 1.3 & $0.307 * * *$ & 2.6 & $0.640^{* * *}$ & 7.4 \\
\hline Observations & 1,509 & & 1,517 & & 1,517 & & 2,153 & & 2,162 & & 2,162 & \\
\hline Adjusted R-squared & 0.228 & & 0.365 & & 0.224 & & 0.197 & & 0.282 & & 0.201 & \\
\hline
\end{tabular}

Source: Author's regression results based on calculations of enterprise survey data. Note: The same note applies as in Table 3. 

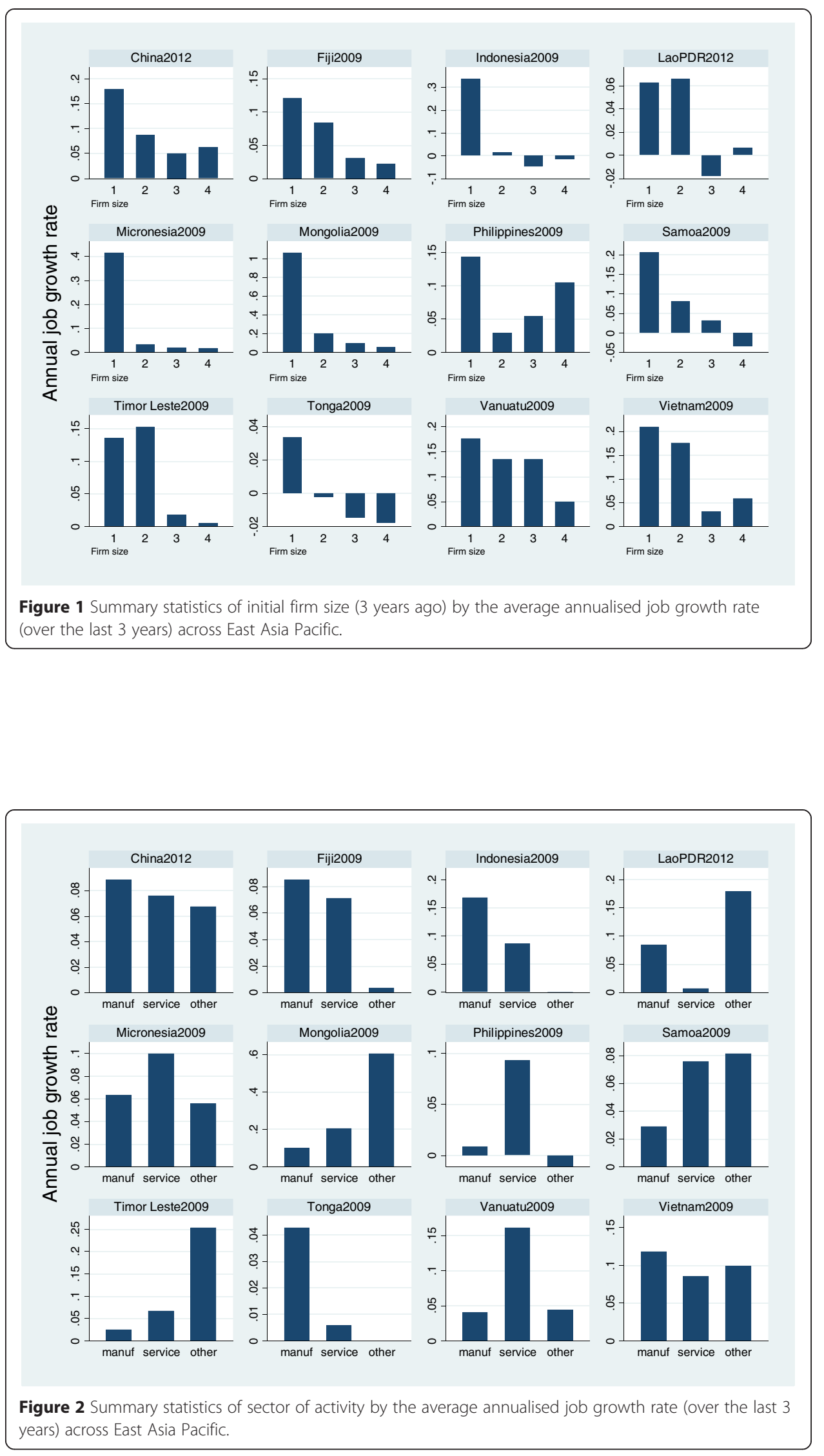


\section{Competing interests}

The IZA Journal of Labor \& Development is committed to the IZA Guiding Principles of Research Integrity. The author declares that he has observed these principles.

\section{Acknowledgements}

This paper was prepared as a background note for the World Bank's (2013a) report At Work in East Asia Pacific. I am grateful for comments from Moritz Meyer, Christian Krekel, Melissa Adelman, Josie Stewart, Tillmann Heidelk and an anonymous journal referee.

Responsible editor: Hartmut Lehmann

Received: 26 January 2015 Accepted: 17 April 2015

Published online: 10 July 2015

\section{References}

Acquisti A, Lehmann H (1999) Job Creation and Job Destruction in Russia: Some Preliminary Evidence from Enterpriselevel Data. LICOS Discussion Paper No.84.

Alby P, Dethier J-J, Straub S (2011) Let There be Light; Firms Operating under Electricity Constraints in Developing Countries. Institut d'Économie Industrielle, Toulouse

Aterido R, Hallward-Driemeier M (2008) Putting African Employment Growth in a Global Context: Impact of Access to Finance, Infrastructure and Regulations Across Firms. World Bank, Washington

Ayyagari M, Demirguc-Kunt A, Maksimovic V (2006) How important are financing constraints? The role of finance in the business environment. World Bank, Washington

Ayyagari M,Demirguc-Kunt A, Maksimovic V (2008) How well do Institutional Theories Explain Firms Perceptions of Property Rights? Review of Financial Studies, 21(4).

Ayyagari M, Demirguc-Kunt A, Maksimovic V (2011) Small vs. Young Firms across the World: Contribution to Employment, Job Creation, and Growth. World Bank, Washington

Beck T, Demirgüç-Kunt A, Maksimovic V (2005) Financial and Legal Constraints to Growth: Does Firm Size Matter? Jinance, vol. 60(1)

Carlin W, Schaffer M (2012) Understanding the Business Environment in South Asia: Evidence from Firm-Level Surveys. World Bank, Washington

Demirgüç-Kunt A, Maksimovic V (1998) Law, Finance and Firm Growth. J Finance.

Dethier J-J, Hirn M, Straub S (2011) Explaining Enterprise Performance in Developing Countries with Business Climate Survey Data. World Bank Res Obs, vol. 26(2).

Dinkelman T (2011) The Effects of Rural Electrification on Employment: New Evidence from South Africa. Am Econ Rev, 101(7).

Djankov S, La Porta R, Lopez-de-Silanes F, Shleifer A. (2002) The Regulation of Entry. Q J Econ, 117(1).

Dollar D, Hallward-Driemeier M, Mengistae T. (2005) Investment Climate and Firm Performance in Developing Economies. Economic Development and Cultural Change, 54(1).

Dutz M, Kessides I, O'Connell S, Willig R (2011) Competition and innovation-driven inclusive growth. World Bank, Washington

Elejalde D, Sheila DG, Stucchi R (2011) Employment Generation, Firm Size and Innovation: Microeconometric Evidence from Argentina. Inter-American Development Bank, Washington

Enterprise Surveys (2013) World Bank's Enterprise Surveys. World Bank/IFC, Washington, www.enterprisesurveys.org/Methodology

Evans D (1987) The Relationship between Firm Growth, Size, and Age: Estimates for 100 Manufacturing Industries. J Ind Econ, 35(4).

Fisman R, Svensson J (2007) Are Corruption and Taxation Really Harmful to Growth? Firm Level Evidence. J Dev Econ, 83(1).

Fox L, Oviedo AM (2008) Institutions and Labor Market Outcomes in Sub-Saharan Africa. World Bank, Washington

Hallward-Driemeier M, Khun-Jush G, Pritchett L (2010) Deals Versus Rules: Policy Implementation Uncertainty and Why Firms Hate It. National Bureau of Economic Research, Cambridge

Haltiwanger J, Vodopivec M. (2002) Gross Worker and Job Flows in a Transition Economy: an Analysis of Estonia. Lab Econ; 9.

IFC (2012) IFC Jobs Study Assessing Private Sector Contributions to Job Creation and Poverty Reduction; Preliminary Findings and Conclusions-Draft. IFC, October, Washington

Klapper L, Laeven L, Rajan R (2004) Business environment and firm entry: Evidence from international data. World Bank, Washington

Krauss A, Graham C (2013) Subjective wellbeing in Colombia: some insights on vulnerability, job security, and relative incomes. Int J Happiness Dev

Movahedi M, Gaussens O (2012) Innovation, productivity, and export: Evidence from SMEs in Lower Normandy, France. University Library of Munich, MPRA, Munich

Pagés C, Aterido R, Hallward-Driemeier M (2007) Investment Climate and Employment Growth. Inter-American Development Bank, Washington

Rajan R, Zingales L (1998) Financial Dependence and Growth. Am Econ Rev, 88(3).

Rankin N, Söderbom M, Teal F (2006) Exporting from Manufacturing Firms in Sub-Saharan Africa. J Afr Econ, 15(4).

Rutkowski J (2003) Does Strict Employment Protection Discourage Job Creation? Evidence from Croatia. World Bank, Washington

Shi A, Michelitsch R (2012) Assessing private sector contributions to job creation: IFC open source study. IFC, Washington

Sutton J (1997) Gibrat's Legacy. J Econ Lit; 35.

World Bank (2004) World Development Report 2005: A Better Investment Climate for Everyone. World Bank and Oxford University Press, Washington and Oxford

World Bank (2012) World Development Report 2013: Jobs. World Bank, Washington

World Bank (2013a) At Work in East Asia Pacific. World Bank, Washington

World Bank (2013b) World Development Indicators Database. World Bank, Washington, http://datacatalog.worldbank.org 